NBER WORKING PAPER SERIES

\author{
COSTS, INSTITUTIONAL MOBILITY \\ BARRIERS, AND MARKET STRUCTURE: \\ ADVERTISING AGENCIES AS \\ MULTIPRODUCT FIRMS
}

\begin{abstract}
Alvin J. Silk
Emst R. Bemdt

Working Paper No. 4826
NATIONAL BUREAU OF ECONOMIC RESEARCH
1050 Massachusetts Avenue
Cambridge, MA 02138
August 1994

Research support from the Division of Research, Harvard Business School, and computational assistance from the MIT Sloan School of Management are gratefully acknowledged. We are also indebted to Crain Communications, Inc. for permission to use their copyrighted data. Responsibility for any remaining errors rests with the authors alone. Earlier versions of this paper were presented at workshops at the University of Florida, Massachusetts Institute of Technology, Harvard University, and the Marketing Science Institute. Working papers are in draft form. This working paper is distributed for purposes of comment and discussion only. It may not be reproduced without permission of the copyright holder. Copies of working papers are available from the author. This paper is part of NBER's research program in Productivity. Any opinions expressed are those of the authors and not those of the National Bureau of Economic Research.

(C) 1994 by Alvin J. Silk and Emst R. Berndt. All rights reserved. Short sections of text, not to exceed two paragraphs, may be quoted without explicit permission provided that full credit, including () notice, is given to the source. 


\title{
COSTS, INSTITUTIONAL MOBILITY \\ BARRIERS, AND MARKET STRUCTURE: ADVERTISING AGENCIES AS MULTIPRODUCT FIRMS
}

\begin{abstract}
What accounts for the diversity and limited concentration that has long characterized the organization of the advertising agency industry? This question is addressed by treating an advertising agency as a multiproduct firm. The firm's product line or service mix is defined in terms of the set of different media categories where an agency places the advertising messages which it creates on behalf of its clients. Evidence is presented indicating that the structure of demand and costs in the advertising agency industry conforms to the conditions that MacDonald and Slivinski (1987) showed were required for an industry to sustain an equilibrium with diversified firms.

Building on this framework, we formulate a set of three hypotheses relating to the realization of product-specific scale and scope economies. The first two hypotheses posit that given low fixed costs and minimal entry barriers, both media-specific scale and scope economies are available and can be exploited by relatively small-size agencies. The third hypothesis suggests that large agencies may experience diseconomies of scope as a consequence of excessive diversification induced by two pervasive industry institutional phenomena: (i) "bundling" of agency services to match client demand for a mix of media advertising; and (ii) "conflict policy" which prohibits an agency from serving competing accounts and operates as a mobility constraint.

Utilizing a multiproduct cost function, we estimate media-specific scale and scope economies for a cross-section of 401 U.S. agencies in 1987. The results obtained support the set of three hypotheses outlined above.

The paper concludes with a discussion of the implications of these findings for the restructuring currently underway in the industry wherein strategies favored by major agencies a decade ago are now being reversed or drastically revised. In particular, the resurgence of interest in small agencies and the trend away from the longstanding reliance on fixed commission rates as the preferred method of agency compensation are in line with our findings on the presence of size-related cost economies. Furthermore, the abandonment of "one stop shopping" and the "unbundling" of the traditional mix of services are interpreted in light of institutional practices which may influence decisions relating to agency efficiency and diversification.
\end{abstract}

Alvin J. Silk

Harvard Business School

Soldiers Field Road

Boston, MA 02163
Emst R. Berndt

Sloan School of Management

M.I.T.

50 Memorial Drive, E52-452

Cambridge, MA 02139

and NBER 
COSTS, INSTITUTIONAL MOBILITY BARRIERS, AND MARKET STRUCTURE: ADVERTISING AGENCIES AS MULTIPRODUCT FIRMS

by Alvin J. Silk and Ernst R. Berndt

\section{INTRODUCTION}

Most of the large body of theoretical and empirical studies of advertising has tended to focus on issues relating to the amount firms expend for advertising, and the effects those outlays have on the behavior of consumers and competitors. 1 As Caves [1986] has discussed, sellers' decisions about the information they supply are influenced not only by the demands of buyers, but also by the costs and technological capabilities of alternative channels and media avallable for transmltting messages. However, economic analysis of the costs and organization of the production of advertising has been meager at best. Sellers typically "buy" rather than "make" the services required to produce and disseminate their advertising messages; the principal suppliers of those services are Independent advertising agencies. An advertising agency generally serves a number of clients for whom it creates and places advertising messages in various communication media. In terms of the basic functions performed, the nature of the services agencies supply has undergone little change since early in the century. Pope [1983, p. 143] has shown that "the evolution from space broker to advertising creator to marketing advisor was quite swift" and that by the early 1920's, the modern "full service agency" had become the predominant organizational form within the industry. However, over time as new communications technologies were introduced, agencies broadened the composition of their output to encompass an ever-expanding array of print and broadcast media alternatives (Benlger [1986]).

In this paper we seek to address a recurring, yet largely neglected question concerning the advertising agency industry, namely, what accounts for the diversity and Iimlted concentration that has long characterized the organization of this industry? 
ADVERTISING AGENCIES AS MULTIPRODUCT FIRMS

- Page 2 -

Our approach here is to treat an advertising agency as a multiproduct firm where its "product line" or service mix is defined in terms of the set of different media categorles where an agency places the advertising messages which 1t creates on behalf of lts clients. We present evidence indicating that the advertising agency industry possesses a number of the characteristics that MacDonald and Slivinskl [1987] have identifled in their model of multiproduct firms as those which give rise to a competitive equilibrium with diversified firms - namely, free entry, low fixed costs, and demand unevenly distributed across products. Moreover, we Identify two additional phenomena that significantly impact market structure. The first is an industry norm known as "conflict policy" which bars an agency from serving competing accounts. We argue that this policy functions as a mobility constraint (Caves and porter [1977]) that Induces growing agencies to diversify into new types of products, rather than to expand in existing ones. The second noteworthy attribute of this industry is that clients generally advertise simultaneously in several media; accordingly, advertising agencies typically "bundle" their services. Together, the joint presence of medla bundling on the demand side and conflict policy on the supply side constitute institutional constraints than induce firms to diversify more extensively than might otherwise be cost-justified. These considerations naturally lead to a set of hypotheses relating the realization of scope and scale economies to the size and product mix characteristics of advertising agencies.

Utilizing the multiproduct agency cost function developed by silk and Berndt [1993], we obtain estimates of product-speciflc scale and scope economies for a cross-section of 401 US agencies. Our results indicate the presence of substantial scale and scope economies for all categories of media output Investigated, and wlde variability among agencles in terms of realizing these economies. Consistent with our hypotheses, we show that this cross-sectional 


\section{ADVERTISING AGENCIES AS MULTIPRODUCT FIRMS}

heterogeneity in product-specific scale and scope economies is related to overall agency size and product-line diversification. Moreover, we report evidence of excess diversification consistent with the existence of conflict policy operating as an institutional mobility barrier.

Our paper proceeds as follows. In Section II we summarize and analyze evidence bearing on the salient features of the advertising agency industry. including posstble sources of economies of scale and scope. In Section III we review MacDonald and Slivinski's [1987] theory of the equilibrium structure of a competitive industry with multiproduct firms, and relate it to the advertising industry. Following that, we review theoretical foundations for the measurement of varlous size-related scale and scope economies in the context of multiproduct cost functions. This theoretical basis enables us to formulate a set of hypotheses which can be investigated empirically. In Section IV we discuss data sources and measurement issues, and then in section $V$ we present empirical findings. The implications of our findings for understanding market structure in the advertising agency industry are the focus of Section VI. Concluding remarks, caveats and suggestlons for further research are given in section VII. Appendix A provides detalled mathematical derivations, while Appendix B presents summary statistics for agency output variables.

\section{THE ADVERTISING AGENCY BUSINESS}

\subsection{Industry Market structure}

The structure of the advertising agency business has long been characterized by two signiflcant features: (a) a relatively low level of concentration, and (b) marked diversity among firms with respect to both the size and composition of their outputs.

In 1977, the share of total U.S. receipts (gross income) earned by all agencies which were captured by the largest 25,100 and 500 firms were 34.97 . 
49.6x and 62.0x, respectively. The comparable figures for 1987 were $33.8 x$, $49.1 x$ and $60.9 x$, respectively. ${ }^{2}$ Thus, the same low level of concentration was maintained over the decade 1977-87. This stability is noteworthy inasmuch as the mid-1980's was a period when takeover activity within the advertising Industry aroused considerable concern and controversy, especially a wave of mergers and acquisitions involving some of the largest Us agencies (Millman [1988]).

According to the definitions and counts found in the 1987 Census of Service Industries (US Bureau of the Census [1989], Table 1a), there were 11,606 advertising agencies (firms) operating in that year. As indicated by the concentration levels noted above, the vast majority of these agencies were very small operations - $52.3 x$ of the agencies operating the entire year in 1987 had gross incomes of less than $\$ 250,000$ (roughly equivalent to billings of $\$ 1.67$ million for ad production and media time and space charges) and $77.3 \%$ had fewer than ten employees (U.S. Bureau of the Census [1989]. Tables 4a and 5a, pp. 1154 and $1-155$, respectively).

The U.S. advertising market consists of two segments of almost equal size, differentiated by the geographical scope of the advertisers' operations: "national" vs. "local" (Owen and Weldman [1992], pp. 11-14). Approximately 55x of total U.S. advertising outlays is accounted for by national advertisers who spend large budgets in media reaching for a broad, national audience (e.g., network television and magazines). The other $45 \%$ is accounted for by local advertisers, primarily retallers, who serve geographically limited markets and utilize media with suitably targeted audiences (e.g., newspapers, and spot radio and television). The presence of numerous local advertisers located throughout the economy supports a diverse array of small, Independent and geographically dispersed agencies. This condition also allows new firms to enter the field on 
ADVERTISING AGENCIES AS MULTIPRODUCT FIRMS

a limited scale and to shift their clientele base over time from local to national advertisers (Rothenberg (1991)).

The principal services that agencies supply to their clients are those associated with the planning of campaigns and the creation, production and placement of advertising messages in different communications media. As shown by Schmalensee, Stlk and Bojanek [1983] and as will be demonstrated further below (Appendix B, Table Bl), agencies differ considerably in regards to the size and composition of their product lines. The latter is manifested in how the volume of advertising an agency produces is distributed across varlous comunications media. Overall, then, the supply of agencies avallable to serve U.S. advertisers is not only abundant in terms of numbers, but also heterogeneous in terms of the scale and scope of their operations.

In line with this market structure, competition anong agencies for clients is intense (Goldman (1992]). The uncertainty surrounding agency-client relations is a pervasfve feature of the advertising industry. A study conducted by the American Association of Advertising Agencies [1985) among 335 of 1ts member agencies found that new clients acquired in 1984 represented the equivalent of $17.6 x$ of all cllents served in the previous year, whlle client losses during 1984 accounted for $13 x$ of those served in the prior year. The median length of all the agency-client relationships in which chis sample of agencies was involved was $3-4$ years.

In selecting a new agency, clfents often invite a numer of agencles to compete for the assignment and then employ a multi-stage screening process to arrive at a final cholce. Advertising performance is difficult to evaluate and agencles have traditionally competed for accounts on the basis of reputation for creativity, service capabilities, and location.

There has been a longstanding debate within the industry as to whether the creative quality of the advertising produced by an agency is related to the 
ADVERTISING AGENCIES AS MULTIPRODUCT FIRMS

agency's size, with many believing the relationship is an inverse one

(Micklethwait [1990], p. 4; Sloan [1992]). As discussed further below, agency operations involve few fixed or sunk costs and in general, the absence of entry (or exit) barriers facilitiates the birth of new firms and serves to enhance competition among agencies (Marshall (1988]). Data reported in the 1977 and 1987 Census of Services indicates that over this period, the number of agencies (firms) operating in the US rose from 7,633 (U.S. Bureau of Census [1977], Table 4, p. 1-99) to 11,606 in 1987, an increase of 52.1\%. Thus, over the 1977-87 decade, the supply of agencies avallable to serve advertisers appears to have grown faster than the level of national advertising expenditures in real terms $(42.17) \cdot 3^{3}$

Finally, for decades, it was standard practice for clients to compensate their agencies via a flat $15 \%$ commission tied to the amount the client expended on media time and space. While studies conducted by the Association of National Advertisers among large national advertisers in 1986 and 1989 indicate that reliance on the $15 \%$ rate has diminished somewhat over time (Association of National Advertisers (1986]; Wellbacher [1989]), the commission system continues to be the dominant mode of agency compensation and the larger the advertiser, the greater the utilization of commissions rather than fees.

\subsection{Demand for Agency Services}

Campaigns undertaken by advertisers typically call for the development and placement of advertising messages in a number of different types of media. Given differences in advertisers' target markets and the composition of audiences for various media, the mix of media selected to deliver advertising messages will tend to vary across industry sectors or product categories. To show the extent of this variability, we examined the 1987 media allocations made by the 200 leading US national advertisers operating in 31 different product categories. The data covered seven major classes of media (newspapers, 
magazines, outdoor, network television, spot television, network radio, and spot radio). As a measure of the extent to which a given advertising expenditure is unevenly allocated across the set of media classes, we computed the value of the Herfindahl Index, $H\left(H-\sum_{j-1}^{n} s_{j}^{2}\right.$ where $s_{j}$ is medium $j$ 's share of total expenditures) for each of the 31 product categories. Note that if some advertising outlay were spread equally across all seven media classes, the value of $H$ would be 0.143 . In fact, we observe that the median value of $H$ for the 31 categories is 0.317 , with the range being from 0.209 to 0.724 , indicating considerable inequality in advertising outlays across media. The significance of this phenomenon becomes apparent when examined in light of a special type of mobility constraint placed on agencies concerning which clients they may serve.

Specifically, an important influence on competition among agencies for clients is the Industry's norm on "conflict policy" which essentially prohibits an agency from serving competing accounts (American Association of Advertising Agencies [1979]). Although agencies create and produce advertising, the standard contractual arrangements stipulate that the property rights to this advertising belong to the advertiser (Weilbacher [1991], chapter 13). In addition to controlling the advertising itself, advertisers also seek to maintain the confidentiality of strategic information which its agency obtains in the course of working together. Hence, the purpose of the conflict policy norm is to prevent the unauthorized leakage of propriety information. While the definition and interpretation of competition is often a matter of dispute between agencies and clients, adherence to the conflict norm is the general practice of the industry ${ }^{4}$ (Siman [1989]). Therefore, in order to add noncompeting accounts, an agency must expand the range of product categories or industries it serves, and so the larger the agency, the more diverse its product account portfolio. 5 Moreover, as discussed further below, given product category 
ADVERTISING AGENCIES AS MULTIPRODUCT FIRMS

differences in the mix of media demanded, growth in agency size will typically also entall greater diversity of media outputs.

\subsection{Agency Cost and Organization Structure}

The sources of potential economies of scale and scope in advertising agency operations may be traced to features of their cost and organizational structures. As suggested by the oft-repeated saw that "an advertising agency is nothing but people" (Mayer [1959], p. 74), the fixed component of agency costs is relatively small as the principal expenses associated with agency operations are labor-related charges. Studies show payroll, bonuses, profit-sharing, and employee benefits average about 60-65x of an agency's gross income (American Association of Advertising Agencies [1987], p. 13 and McDonald [1989]). Agency employment levels are notorlously sensitive to changes in economic conditions and client turnover.

Agencies typically employ some form of matrix organization (Comanor, Kover and Smiley (1981]; McNamara [1990]). Such a structure reflects the division of labor occurring within an agency involving specialization along two dimensions: (a) function or task, e.g., creative, production, media, research and/or client contact; and (b) type of output, differentiated on the basis of communication medium, e.g., broadcast, print, direct response, promotion, public relations. These patterns are displayed in Figure 1 .

\section{INSERT FIGURE 1 ABOUT HERE}

While structured into departments corresponding to the basic functions an agency performs for lts clients, an agency deploys its professional personnel in account teams, each of which is staffed by a group of functional specialists and assigned to serve a specific client. 
ADVERTISING AGENCIES AS MULTIPRODUCT FIRMS

These basic features of agency operations -. labor intensiveness and matrix organization -- embody various aspects of shared costs, specialization and Imperfect divisibility of Inputs that are phenomena generally identified as the antecedents of scale and scope economies. To illustrate, experienced Industry practitioners have observed that the size and composition of an account team required to serve a client tends to remain relatively fixed over a considerable range of variations in the size of accounts, as measured by the amount a client expends for media time and space (We1lbacher [1991)). In a similar vein, an agency's costs of performing certain functions may vary by medium because media differ with respect to their divisibility and minimum transaction size (Poltrack [1983], Porter [1976]).

While these phenomena bear directly on a number of controversial industry issues such as the economic rationales for merger and acquisitions, and agency compensation methods, they have not been subjected to a great deal of systematic empirical study. Recently, however, Silk and Berndt (1993) reported results of an econometric study which showed that global scale and scope economies play a major role in determining agency costs. As elaborated below, here we extend that work to investigate product-specific scale and scope economies.

Clearly, clients' demands for agency services reflects the wix of media employed to satisfy their campaign goals. The presence of economies of scale and scope in jolntly producing and placing advertising for that mix of media suggests a plausible rationale for advertising agencies operating as multiproduct firms who are capable of efficiently supplying the set of mediarelated services demanded by clients. We now briefly review some relevant economic theory and relate it to advertising agency operations. 
III. THE UNDERLYING ECONOMIC THEORY OF MULTIPRODUCT FIRMS

\subsection{Market Equilibrium with Multiproduct Firms}

The nature of competitive equilibrium and market structure in the context of multiproduct firms has received relatively little theoretical attention and, to the best of our knowledge, hardly any empirical examination. Here we wish to focus on how the (apparently stable) structure of the advertising agency industry is affected by technology, demand, and institutional mobility constraints. As we shall now see, it is useful to begin by summarizing the theoretical results reported by MacDonald and Slivinski [1987] - hereafter, MS.

MS consider a two-product market model in which firms can either specialize (produce only one good) or diversify (produce both goods). The structure of the industry in competitive equilibrium is shown to take one of three forms: (i) all firms diversified, none specialized; (ii) all firms specialized, none diversified; (iii) diversified firms and only one type of specialized firm operate contiguously. Which of these three equilibria occurs depends on costs and demands.

Specifically, when the fixed costs of diversified firms are sufficiently low, a diversifled equilibrium will obtain. Moreover, in a diversification equilibrium, all firms will be identical in their output mix ("politically correct diversification"). For intermediate values of the fixed cost, the mixed outcome with only one type of specialized firm (producing, say, good $j$ ) is more likely when demand is skewed toward good $f$, and is more likely to be a diversified equilibrium when demand is symmetric. The extent of demand skewing required to generate the mixed eqilibrium is smaller, the larger is the diversified firm's fixed costs. Finally, in the mixed equilibrium with diversified and only one type of specialized firms, the specialized firms play an "industry fringe" or buffer role, absorbing all variations in demand for the good they produce. 
It is useful to relate the MS results to the structure of the advertising agency Industry, as described in Section II, and to the empirical estimates of global scale and scope economies reported in Silk and Berndt [1993]. Specifically, the fact that concentration is relatively low and that there are thousands of firms in this industry in the US is consistent with the evidence cited earlier Indicating that fixed costs do not constitute an effective barrier to entry. The Implication of this set of conditions is that scale economies can be realized at relatively small levels of output. Furthermore, the fact that almost all firms in this industry are multiproduct rather than single-product firms (86\% of the sample of agencles discussed below produce six or more outputs) suggests that the incremental fixed costs of being diversified rather than specialized axe not substantial, and that economies of scope can also be realized and exploited by relatively small-sized firms. Finally, since the pattern of diversification is non-uniform across firms (about $19 x$ of the agencies in our sample produce six outputs, $23 \%$ produce seven outputs, $26 \%$ eight outputs, and $18 \pi$ nine outputs), the existence of a diversified equilibrium suggests that demand skewness may have a significant impact on industry structure. In particular, as noted in Section II.1, small advertising agencies tend to play a fringe role in the national advertising market by serving geographically-specific niches.

In addition to these traditional cost and demand factors facing the advertising agency industry, the existence of an institutional norm constraining mobllity behavior - namely, the aforementioned "conflict policy" may generate further incentives to diversify. To see this, recall that as discussed in Section 2.2, within any product category or industry, empirically it is the case that advertising expenditures tend to be unevenly distributed across media categories. Moreover, and very Important in our context, this media skewness varies markedly across industries and their products. If an advertising agency 
wishes to expand, it is therefore much more likely to find a conflicting client

within 1ts existing set of media than it is by expanding into other media.

Hence, by adding another media to its service mix rather than expanding within current media, an advertising agency is more likely to find a client in an Industry different from those industries already being served, $1 . e .$, to find a non-conflicting client. This suggests, therefore, that in order to mitigate the adverse effects of client conflict conventions, the larger the size of an advertising agency, the more likely it is to expand its mix of media beyond that which is strictly cost-justified.

In this paper we will analyze empirfcally the relationships among scale economies, scope economies, and firm size in the advertising agency industry. We will also examine whether measures of scope economies suggest that these conflict conventions have impacted costs in a negative manner. To undertake such an analysis, it is first necessary to formulate a model in which these concepts are clearly defined. To that we now turn our attention.

\subsection{Models of Scale and Scope Economies}

In order to understand better the Implications of scope and scale economies for industry structure, it is necessary to define more rigorously the notions of global economies of scope and scale, and in particular, to distinguish these notions from product-specific economies of scope and scale. We begin with the overly simplified single-product of conventional economics textbooks, in which the average cost function is approximately L-shaped, with average cost approaching an asymptotic lower bound as a scale-related $\mathrm{Z}$ variable approaches infinity. A reasonable specification for a cost function having such a shape is:

$$
\mathrm{U}=\alpha+\beta \mathrm{e}^{-\gamma \mathrm{z}},
$$

where $U$ is a measure of average cost, $Z$ is a scale-related variable, and $\alpha, \beta$ and $\gamma$ are (assumed positive) parameters. This function is illustrated in Figure 
2 below; its shape is broadly consistent with the literature on economies of scale in many industries (Johnston [1960, Ch. 4)). 6

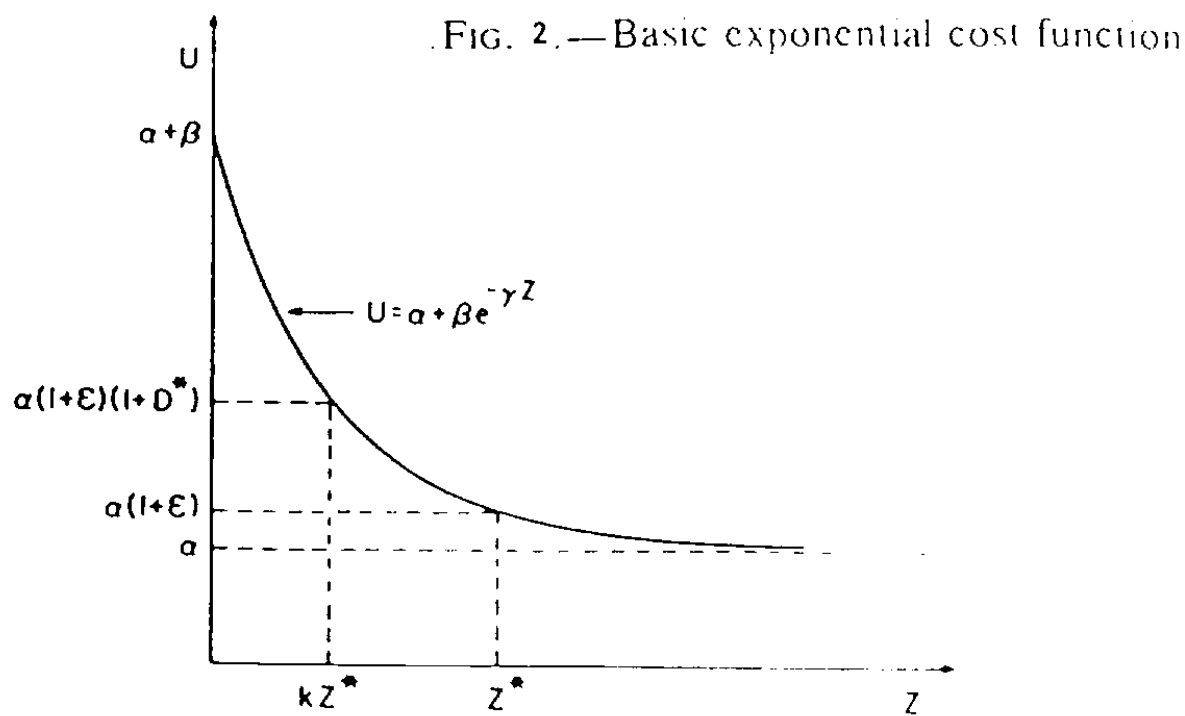

Given positive values of the parameters, Eq. (1) postulates that U is an everywhere-decreasing function of $z$, implying there is no finite $z$ at which scale economies are entirely exhausted. Note that as $\mathrm{Z} \rightarrow \infty, \mathrm{U} \rightarrow a$. One can say that scale economies are essentially exhausted for a firm of size $Z^{\star}$ if $U\left(Z^{\star}\right)-$ $(1+\epsilon) \alpha$, where $\epsilon$ is a small number. Solving for $z^{\star}$, we obtain an indicator of minimum efficient scale as:

$$
z^{\star}=-(1 / \gamma) \ln (\alpha \epsilon / \beta)
$$

where we might set $\epsilon-.01$, so that a scale of $z^{*}$ corresponds to costs one percent above the asymptotic minimum.

Instead of assuming that firms produce but one product, we now become more realistic and consider a firm producing $N$ different outputs or services. In this case Eq. (1), with $j$ subscripts everywhere, refers to the unit cost of the $j^{\text {th }}$ service product where the unit cost term $U$ is re-defined as total costs divided by gross income $\left(Y_{j}\right)$. Multiplying by the revenue share $S_{j}$ and summing, we can obtain the basic equation for long-run costs as: 


$$
U=\sum_{j=1}^{N} a_{j} s_{j}+\sum_{j=1}^{N} \beta_{j} s_{j} \exp \left(-\gamma_{j} z_{j}\right)
$$

Depending on the specification, $Z$ can take on alternative functions of all the output levels. In Silk and Berndt [1993], a variety of formulations of the $Z$ scale variable were considered, both theoretically and empirically. In the most general version of their preferred cost specification, the scale variable for each service product is simply the overall size of the $i^{\text {th }}$ agency, measured by gross income $Y_{1}$, where $Y_{1}=\sum_{j} Y_{1 j}$ and $Y_{1 j}$ is the $1^{\text {th }}$ firm's gross income from medium $\mathrm{j}$ :

$$
U_{1}-\sum_{j=1}^{N} a_{j} s_{1 j}+\sum_{j=1}^{N} \beta_{j} s_{1 j} \exp \left(-\gamma_{j} Y_{i}\right)+u_{1}
$$

where the $u_{i}$ are assumed to be normal disturbance terms with all the usual desirable properties. Silk and Berndt reported that in the preferred empirical model, the parameter restrictions $\gamma_{\mathrm{f}}-\gamma$ and $\beta_{\mathrm{j}}-\beta, \mathrm{j}-1, \ldots, \mathrm{N}$, were imposed. ${ }^{7}$ Hereafter we incorporate those parameter constraints.

The above formulation of a multiproduct cost function accommodates global economies of scope. To see this, recall that what global scope economies refer to is the cost savings to a firm from producing $N$ multiple services, rather than splitting the firm up into $N$ smaller firms, each specializing in producing one and only one service output. ${ }^{8}$ More specifically, let $C$ be total (not average) costs, and define total costs $C_{\text {Split }}$ for the notional split-up multiservice firm as the sum of costs from producing each of the $N$ services at $N$ distinct singleservice subsidiaries (where subscripts now refer to products or services, not firms):

$$
C_{\text {Split }}=c\left(Y_{1}, 0, \ldots 0\right)+c\left(0, Y_{2}, 0, \ldots 0\right)+\cdots+c\left(0, \ldots, 0, Y_{N}\right)
$$


Total costs for the multiproduct firm jointly producing all $N$ outputs are $C_{J \circ}$ int - $C\left(Y_{1}, Y_{2}, \ldots, Y_{N}\right)$. Global returns to scope (RSP) are then simply computed as the percent cost savings due to producing outputs jointly rather than separately, i.e..

$$
\text { RSP }=\frac{C_{\text {Split }}-C_{\text {Jo1nt }}}{C_{\text {joint }}} .
$$

Hence, when global RSP are positive, $C_{J o i n t}<C_{S p l i t}$, and there are cost advantanges to being a multiproduct firm, deriving perhaps from specialization and the joint utilization of shared inputs. When RSP are zero, no such cost advantages emerge, and if RSP were negative, the firm could reduce its costs by splitting up. The fact that it is rare for an agency to create and place advertising in a single medium suggests that RSP are available. 9

The scale and scope cost function presented in Eq. (4) allows for non-zero global scope economies. Noting that $s_{i j}-1$ for the firm producing only the $j^{\text {th }}$ output, that for such firms $Y_{1}-Y_{1 j}$, and setting the $u_{i}-0, C_{s p l i t}$ turns out to be:

$$
C_{\text {Split }}=\sum_{j=1}^{N} \alpha_{j} Y_{1 j}+\sum_{j=1}^{N} \beta \cdot Y_{1 j} \exp \left(-\gamma \cdot Y_{1 j}\right)
$$

On the other hand, since $S_{1 j}-Y_{i j} / Y_{1} \Rightarrow Y_{1} S_{1 j}-Y_{1 j}$, it follows that for the speciflcation in Eq. (4), C Joint equals:

$$
C_{J \circ i n t}-\sum_{j=1}^{N} \alpha_{j} Y_{i j}+\sum_{j=1}^{N} \beta \cdot Y_{1 j} \exp \left(-\gamma \cdot Y_{i}\right)
$$

We can therefore write the expression for global returns to scope (RSP) for agency 1 from Eq. (6) corresponding to the multiproduct cost function from Eq. (4) as: 


$$
\left.R S P_{i}-\sum_{j=1}^{N} \beta \cdot Y_{1 j}\left[\exp \left(-\gamma \cdot Y_{i j}\right)-\exp \left(-\gamma \cdot Y_{i}\right)\right]\right) / C_{J o i n t}
$$

Note that the expression in the numerator of (9), $C_{S p l i t}-C_{J o i n t}$, does not depend on the $\alpha^{\prime} s$, but will typlcally be non-zero because $\exp \left(-\gamma \cdot Y_{1 j}\right) t$ $\exp \left(-\boldsymbol{\gamma} \cdot \mathrm{Y}_{1}\right)$, Implying that in general $\mathrm{RSP}_{1} \neq 0$.

Before distingulshing global from product-specific economies of scope, we briefly consider measures of scale economles. In a model with multiple service outputs, the traditional measure of returns to scale is ambiguous. To see this, recall that in the case of a single product firm, the traditional measure of returns to scale 1 s the ratlo of average cost $(C / Y)$ to marginal cost $(\partial C / \partial Y)$. In the multi-service case, however, the notion of average cost is not welldefined (by which output does one divide total costs?), and product mix could change with overall slze (by how much does one change the various outputs?). There are several ways to overcome this problem.

First, one can define a returns to scale notion as that based on the effects on total costs when all services are Increased proportionately, i.e. holding service output $\mathrm{mix}$ constant. This concept is called global or rayreturns to scale (overall slze expands on a linear ray in output space; see Balley and Friedlaender [1982]). In our context, define global or ray returns to scale $\left(R R S_{1}\right.$ ) as the ratio of average to marginal cost for $Y_{1}$ where $Y_{1}=$ $\sum_{j} Y_{1 j}$, holding service output mix fixed:

$$
R_{i}-\frac{C / Y_{i}}{\partial C / \partial Y_{i}} \mid s_{i j}-\bar{s}_{i j}
$$

For the cost function In Eq. (4), ray returns to scale turn out to be: 


$$
R R S_{1}-\frac{\sum_{j-1}^{N} \alpha_{j} S_{1 j}+\sum_{j=1}^{N} \beta \cdot S_{1 j} \exp \left(-\gamma \cdot Y_{1}\right)}{\sum_{j=1}^{N} \alpha_{j} S_{1 j}+\sum_{j=1}^{N} \beta \cdot S_{1 j} \exp \left(-\gamma \cdot Y_{1}\right) \cdot \sum_{j=1}^{N} \gamma \cdot \beta \cdot Y_{1 j} \exp \left(-\gamma \cdot Y_{i}\right)} .
$$

An alternative measure of scale economies that is very useful in the context of multiproduct firms is that of medium-specific scale economies; it is due to Balley-Frledlaender [1982, p. 1030]. For output J, medium-specific returns to scale, $\mathrm{SCL}_{1 \mathrm{j}}$, Is defined as the ratio of average incremental cost, $\mathrm{AIC}_{1 \mathrm{j}}$, to marginal cost, $\mathrm{MC}_{1 \mathrm{j}}$ :

$$
\mathrm{SCL}_{1 j}-\mathrm{AIC}_{1 j} / \mathrm{MC}_{1 j} \text {. }
$$

where average incremental cost is defined as the incremental average cost of adding a new product $f$ to a flrm previously having only $N-1$ product 1 ines,

$$
A I C_{1 j}=\left[C\left(Y_{1, N}\right)-C\left(Y_{1, N-j}\right)\right] / Y_{1 j} \text {, }
$$

where $C\left(Y_{1, N}\right)$ Is the total cost to firm 1 of producing all $N$ outputs and $C\left(Y_{i, N-j}\right)$ is the total cost of producing all $\mathrm{N}$ outputs except output $j$, and where $M C_{1 j}$ is defined as the traditional $M C_{1 j}=\partial C\left(Y_{i, N}\right) / \partial Y_{1 j}$. For the multiproduct cost function of Eq. (4), product-specific returns to scale turn out to equal (see Appendix A for detalls of this derivation):

$$
\operatorname{sCL}_{1 j}-\frac{\alpha_{j}-\sum_{k-1}^{N-1} \alpha_{k} S_{1 k}+\frac{\beta}{s_{1 j}}\left[1-\left(1-s_{1 j}\right) \cdot \exp \left(-\gamma S_{1 j} Y_{1 N}\right)\right] \cdot \exp \left(\gamma Y_{1 N}\right)}{\alpha_{j}+\left[1+\gamma Y_{1 N}\right] \cdot \beta \cdot \exp \left(\gamma Y_{1 N}\right)}
$$

where $k \neq j$. Note from Eq. 11 that while RRS for firm $i$ (ray returns to scale) quantifles global scale economies as all $\mathrm{N}$ outputs are increased by the same proportion, product-specific scale economies, $\mathrm{SCL}_{\mathrm{ij}}$, based on $\mathrm{Eq}$. 14 computes scale economies assuming that the amount of output $j$ is increased from zero to 
ADVERTISING AGENCIES AS MULTIPRODUCT FIRMS

- Page 18 .

some finite number, whlle all other outputs are held fixed. Hence, while RRS

is computed as $A C_{1} / M_{1}, S C L_{1 j}-A I C_{1 j} / M_{1 j}$.

For our purposes, it will be informative to calculate product-specific

scope economies for firm 1, which we denote as $\mathrm{SCP}_{\mathrm{ij}}$. The intuition behind this calculation is to quantify cost savings for producing output $j$ jointly but

Incrementally (given production of the $\mathrm{N}-\mathrm{j}$ other outputs) compared to producing output $j$ separately. Note in particular that the cost comparison here is not as dramatic as that for global scope economies (unless there are only two outputs, In which case global and product-specific scope economy measures are identical); here we examine a more "marginal" situation in which a firm considers adding one more product to its existing set of products, and determines whether it is more cost effective to produce it within the firm or to produce it via a subsidiary. In particular, the firm is not consldering the possibility of producing all its products in separate subsidiarles.

Following Wang and Frledlaender [1985, p. 253], one can therefore define product-specific scope economles as:

$$
S C P_{1 j}=\frac{C\left(Y_{1 j}\right)-\left[C\left(Y_{1, N}\right)-C\left(Y_{1, N-j}\right)\right]}{C\left(Y_{1 N}\right)}
$$

where $C\left(Y_{i j}\right)$ is the total cost of producing $Y_{i j}$ separately, and $C\left(Y_{i, N}\right)$ and $C\left(Y_{1, N-j}\right)$ are, respectively, total costs when all $N$, and all $N$ except $j$, outputs are produced Jointly by f1rm 1 . Thus Eq. 15 represents the percent cost savings (dissavings) realized by producling output $j$ fointly, rather than separately.

For the multiproduct cost function of Eq. (4), product-specific scope economies turn out to be (see Appendix A for a more complete derivation), where $j \neq k$ and m denotes specific media output m: 


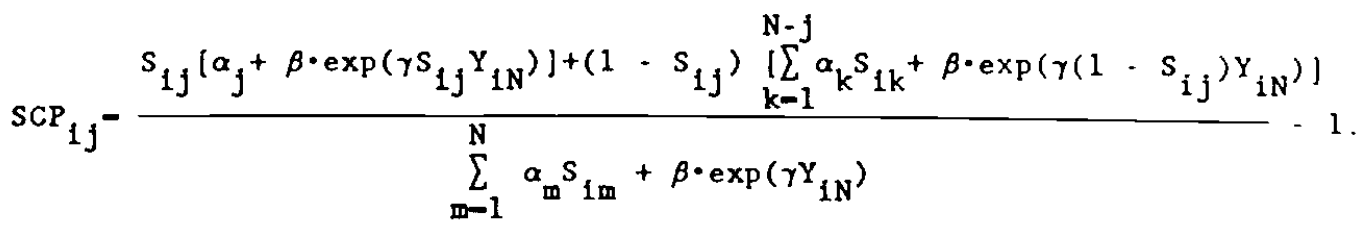

Although Silk and Berndt [1993] did not consider of product-specific scale and scope economies, they did report estimates of global scale and scope economies. In terms of scale, silk-Berndt reported that the minimum efficient size agency had gross income of $\$ 3-4$ million (equivalently, billings of $\$ 20-27$ million). Thus of the almost 12,0000 firms comprising the industry in 1987 , approximately 200-250 had operating levels sufficlently large to take full advantage of all available size-related efficiencies; these 200-250 firms accounted for about $57 x$ of total industry output (gross income). For firms operating at only $50 z$ of minimum efficient scale, however, the cost penalty was substantial -. varying from 8 to $15 x$, depending on the medium. Thus, while potential global scale economies are important, they have been exploited by a large number of firms. With respect to estimated global economies of scope, Silk-Berndt reported that the sample median cost savings attributable to joint production were about $26 x$. Further, although global scope economies were exhausted for the very largest firms, scope economies were of considerable consequence for smaller agencles in that their costs were highly sensitive to the mix of media services provided.

With this as background, we now ask: What should one expect in a competitive equilibrium in terms of product-specific economies of scope and scale? First, it bears noting that the existence of a diversified equilibrium in the advertising agency industry is not necessarily inconsistent with the presence or absence of global economies of scope, since that concept refers to an "all or nothing" total cost comparison involving totally integrated vs totally atomistic product line production. 
ADVERTISING AGENCIES AS MULTIPRODUCT FIRMS

However, we would expect that at the margin, any multiproduct firm would not expand products into the region of negative product-specific scope economies, for another firm could enter without producing that product line and would therefore not experlence that cost disadvantage. Hence, in a competitive equilibrium, we would not expect product-specific scope economies to differ substantially from zero. A simflar line of reasoning suggests that we should also expect that in a competitive equilibrium, product-specific scale economies would be exhausted as well.

Recall from our earlier discussion that there are two reasons we might expect to find product-specific diseconomies of scope. First, as discussed in Section 2.2, the typical advertiser usually places advertising in a set of media, and hence an agency must supply a bundle or mix of media services simultaneously. Unbundling would impose transactions costs on the advertiser (see Teece (1982\}). Second, as also discussed in Section 2.2, in this industry we observe the presence of a very special institutional mobility constraint in the form of conflict policy, which essentially prohibits an agency from serving competing accounts. With conflict policy, firms face incentives to expand by diversifying into other product lines.

In summary, together the joint presence of media bundling on the demand side and conflict policy on the supply side constitute institutional constraints which may give rise to cost inefficiencies such as diseconomies of scope. 10 Having discussed and rigorously defined the concepts of product-specific economies of scale and scope, we can now formulate three hypotheses about the nature of size-related economies in the advertising agency industry:

(1) Product-speciflc scale economles can be realized at relatively low levels of output. The argument underlying this prediction is that fixed costs are low and do not constitute an effective barrier to entry. (ii) Product-specific economies of scope can be realized and exploited by relatively small-sized 
firms. This proposition follows from our conjecture that the incremental fixed costs of belng diversifled vs. speclalized are not substantial. (iii) The larger the size of an agency, ceterls parlbus, the more likely it is to expand its media $m i x$ beyond that which is strictly cost-justified (into the region of negative product-specific economies of scope), in order to mitigate the adverse effects of client conflict strictures. As argued above, we expect this to occur, since given product category differences in media mix, the existence of a conflict policy induces agencles that seek to grow to diversify their product mix rather than to expand existing product lines.

We now describe our data base, and then present empirical evidence on product-specific economies of scale and scope.

\section{DATA BASE DESCRIPTION AND VARIABLE DEFINITIONS}

The data base we ut1lize in our empirical study consists of a set of 1987 operating results for a cross section of 401 agencles compiled by Advertising Age [1988]. The sample contains a broad distribution of agencies of different slzes serving a diverse body of clients by producing advertising for dissemination through a wide varlety of media. 11 A noteworthy feature of the data collection procedure was that particlpating agencies were asked to submit a statement signed by an Independent accountant verifying the data report.

The definitions of the variables and measures employed in our analysis are as follows :

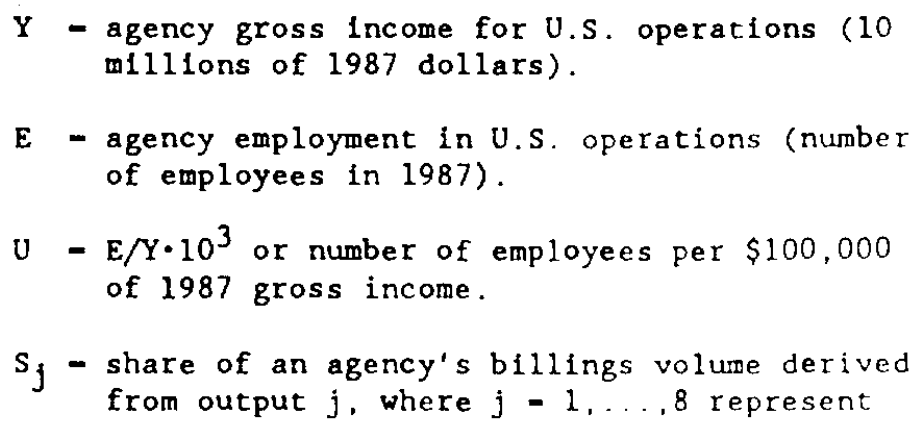


ADVERTISING AGENCIES AS MULTIPRODUCT FIRMS

$$
\begin{aligned}
& \text { alternative media categories and } j-9 \text { denotes } \\
& \text { billings and/or capitalized fees derived from } \\
& \text { all non-media specific services. } \\
& Y_{j}-S_{j} \cdot Y-\text { estimated gross income from output } j .
\end{aligned}
$$

An agency's gross income is best interpreted as the equivalent of the usual accounting definition of "gross margin" or the difference between sales receipts and cost of goods sold. Gross income $Y_{i}$ for US operations of firm $i$ (in tens of millions of 1987 dollars) is computed as the sum of revenues it receives from (i) commissions earned from purchases of media time and space made on behalf of clients; (11) markups on materials and services purchased from other suppliers and then charged to clients; and (iii) fees paid by clients for agency services in addition to or in lieu of the aforementioned commissions and markups. Within the industry, gross income is often used in analyses of agency "productivity" and is regarded as the preferred measure of agency size or output because it is more meaningful for comparative or cross sectional analysis than other indicators such as billings volume or capitalized billings, the latter of which may give a misleading picture of output or scale due to variations across agencles in media and service mixes and compensation methods (Gardner [1976) and Paster (1980]).

As a proxy for an agency's average cost $U_{1}$, we employ "number of employees per hundred thousand dollars of gross income," and thereby implicitly assume the absence of systematic cross-sectional wage differentials. As noted earlier, studies indicate that labor costs (payroll, bonuses, profit-sharing, and related employee benefits such as insurance and retirement), typically acount for about two-thirds of an agency's total expenses. Given the reasons discussed above for preferring gross income over billings as a measure of agency output, it is also advantageous to measure unit cost by the ratio of employees to gross income rather than "employees per million dollars of billings". 
The data reported in Advertising Age [1988] encompassed billings in fifteen distinct media categories. We have combined some of the minor media to arrive at a set of nine separate categories: network television (TVL), spot television (TVH), general magazines (MGL), specialty print (PTH), newspapers $(N P H)$, direct response (DRH), radio $(R D H)$, display (DSP) and non-media services (XMB). "Display" is an aggregation of four small media types: outdoor, point of sale, transit, and special events. The "non-media" share of billings encompasses a broad spectrum of services, the composition of which may vary across agencies. Included here are ad production and specialized services or projects such as marketing research, public relations, and sales promotion. Further discussion of the measurement issues posed by the heterogeneity of this category is given in Silk and Berndt [1993].

The share of an agency's billings volume in each media/service category, $s_{j}$, is assumed to be an unblased estimate of the share of its gross income attributable to that category of output. It is worth noting that this assumption is strictly valid only if the ratio of gross income to billings is a constant for all categories of output within each agency (but not necessarily fixed across agencies). As discussed by McNamara ([1990], pp. 140-141), while margins may vary among accounts served within a particular agency (according to client size and method of compensation), in general clients tend to favor constant margins across media in order to remove any incentive for the agency to favor one medium over another. Unfortunately, the information required to check this condition directly is not avallable. ${ }^{2}$ Given data on $Y$ and $s_{j}$ for firm $i$, we therefore compute estimated gross income from output $j, Y_{i j}$, as $Y_{1 j}=S_{i j} \cdot Y_{i}$. The data utilized here do not include results for international activities. Subsidiaries and conglomerate agencies were treated as distinct firms. In the case of ten "mega-agencies," the results for their subsidiaries were excluded from the parent firm data in line with the information on these 
relationships reported in Advertising Age [1988, pp. 4 and 96]. Further details on these variables and data sources are given in Silk-Berndt ([1992], Appendix A).

\section{EMPIRICAL FINDINGS}

In this section we present estimates of medium-specific scale and scope economies for our sample of 401 agencies, calculated using the parameter estimates from our preferred unit cost model Eq. (4). For each agency, we computed the values of $S_{C L}$ and $S C P_{i j}$, the indices of product-specific scale and scope economies defined above in Eqs. (14) and (16), respectively, for all of the media categories $(j-1, \ldots 9)$ where the agency's output was nonzero. These two equations are highly nonlinear functions of agency-specific variables (media shares and gross income) and the estimated parameters. Note that one parameter, $\alpha_{j}$.- the asymptotic unit cost of the $j^{\text {th }}$ media (employees per $\$ 100,000$ of gross income) - plays a critical role in these scale and scope calculations. In Silk and Berndt [1993] a variety of test results were reported involving the $\alpha_{f}$ parameters; the preferred specification restricted several of these $\alpha_{j}$ 's to be equal across subsets of the nine media. In particular, for network television, spot television, general magazines, and specialty print, $\alpha-$ 0.74 ; for newspapers and direct response, $\alpha-1.32$; for non-media services, $\alpha-$ 1.57 ; and for radio and display, $\alpha-2.17 .13$

Given these differences in the $\alpha^{\prime} s$, we therefore expect associated variability in the mean levels of scale and scope economies across media.

\subsection{Medium-Specific Scale Economies}

In Table 1 we present sumary statistics for the set of medium-specific scale estimates. In line with the nature of our model specification which posits unit cost to be an everywhere decreasing function of output, we find empirically that the values of virtually all of the scale economy indices exceed 
unity, signifying that to varying degrees, the costs of agency operations in different media categories are subject to increasing returns to scale.

INSERT TABLE 1 ABOUT HERE

Within each media category, the distribution of scale economies is fairly symmetric, as evidenced by the fact that differences between the means and medians are quite small. Thus, the agencies active within any particular media cateogry tend be highly diverse with respect to operating efficiency as judged by the extent to which they are able to realize potential scale economies. This confirms the diversity we expected. 14

Comparing the values of the medians (or means) in Table 1 across media categories, we observe that scale economies tend to be least exploited for the set of four media categorles consisting of network television, spot television, general magazines and speciality print; here the median values of the index of scale economies are quite high, ranging from about 2.6 to 2.8 . Realization of scale economies is somewhat greater for newspapers and direct response $(\mathrm{SCL} \approx 2)$ and is most prevalent for radio and the two hetereogeneous categories, "display" and non-media services; here the median SCL's are in the vicinity of 1.4 to 1.6 .

In order to examine whether this marked varlability is consistent with our hypothesis that product-specific scale economies can be realized at relatively low levels of output, we examined the relationship between scale economies and agency size by regressing our measure of scale economies, $\mathrm{SCL}_{1 j}$, on the logarithm of agency gross income and a set of additional descriptor variables that capture the basic features of an agency's outputs. Note that the inclusion of these other variables in addition to size enables us to control for the impacts of the covariates also affecting measures of scale and scope in Eqs (14) and (16). Results from these regressions are presented in Appendix $C$. 
Based on the parameter estimates of these regressions, we calculated the predicted economies of scale as a function of agency size and the other variables, where all other variables were evaluated at the sample wedian. Next we compared the measure of predicted scale economies for two different agency sizes: an agency whose slze equalled the sample median $(\$ 3.2$ million of gross Income), and a smaller agency only one-half that size. We then computed the percent difference In the predicted scale economy Index, which may be Interpreted as the percent loss in efficlency by being $50 x$ smaller than the median-slzed agency. If this percent difference is very small, then that would suggest that product-specific scale economies could be attained by very small agencles, and that even if one were only half the industry norm, most scale economies could be explodted. We find that these percentage efficiency losses are indeed very swall. In particular, they range from $1.35 \%$ for display advertising to $4.77 \%$ for magazine advertising.

We conclude, therefore, that our first hypothesis is supported by the emplrical evidence, 1.e., product-specific scale economies can be realized at relatively low levels of output.

\subsection{Medium-Specific Scope Economles}

Sumary statistics for our measures of product-specific scope economies are given in Table 2. The first noteworthy feature of these results is that the median value of the scope economles Index for each of the nine media categorles Is approximately zero, signifylng that the typical agency active in any of these domains is operating in a manner such that it has essentially already exhausted the avallable economies of scope. An implication of these results is that, for the typical agency active in any medla category, there does not appear to be a discernible cost advantage assoclated with producing one more category of media advertising, given the joint production of the remainder of the typical agency's media mix. 
However, as was the case with scale economies, within each of the media categories, the importance of scope economies appears to vary substantially across agencies. The range of estimated scope economies coefficients is quite broad (especially for network and spot television and non-media services) and encompasses both positive and negative values in all nine media categories. Furthermore, the distributions of the scope indices tend to be noticeably skewed in the direction of negative values. Thus, we find that although some agencies realize a substantial cost advantage through the joint production of the mix of media advertising they supply $\left(\mathrm{SCP}_{i j}>0\right.$, economies of scope), for many other agencies there appears to be a pronounced cost disadvantage associated with producing their mixes of media advertising jointly, rather than dropping one media $\left(\mathrm{SCP}_{i j}<0\right.$, diseconomies of scope).

INSERT TABLE 2 HERE

A clearer picture of the cross-category variability with respect to scope economies may be obtained by examining the percentages of agencies operating in each media category for whom joint production of that output is more efficient than producing it separately from the other components of the media mix--i.e., the percent of agencies for whom $\mathrm{SCP}_{i j}>0$. As can be seen from Table 3 , those percentages range from a low of approximately 50\% (network and spot television) to highs of $78 \%$ and $85 \%$ for the direct response and display categories. respectively. These results are clearly consistent with our second hypothesis, that scope economies were available and could be exploited by relatively smallsized firms.

Concerning our third hypothesis and possible evidence for excess diversification, note that within each of these media categories there are, in varying numbers, agencies whose operations are subject to some measure of 
diseconomies of scope and who, as a consequence, wight achleve cost savings by reducing output and consolidating their media mixes. Recall from our earlier discussion that the existence of product bundling on the demand side and conflict policy on the supply side could lead firms to undertake excessive diversification.

To Investigate this hypothesis, we regressed the measure of scope economies on the logarithm of agency size and the same set of agency descriptor variables used in the above scale economy analyses. The results of these regressions are presented in Appendix $C$. Consistent with our hypothesis, scope economies were found to be negatively related to agency size, ceteris paribus. Hence, together the result in Table 2 that anywhere from only $15 \%$ to as much as 527 of agencles were operating in reglons with product-specific diseconomies of scope, and the finding that scope economies and size are negatively related, provide clear support for our third hypothesis: the larger the size of the agency, ceterls paribus, the more likely an agency is to expand its media mix beyond that which is strictly cost-justified.

\section{DISCUSSION}

The advertising agency business is presently in an unsettled state as the advertising Industry as a whole struggles to adapt itself to changing economic conditions and the onslaught of new communications technology (Mayer [1991]; Sellers (1993]). As a senior executive of one mafor agency put it, "The traditional agency as we have known it will not exist in the next five years. We're going to see an incredible amount of change... for the first time in five decades there is a reinvention of the industry as we know it" (Wells and sloan [1993b, p. 28]).

The fundamental strategic issues facing agencies are essentially the twin questions of scope and scale: (1) What mix of services should be offered 
clients? and (ii) How large should an agency be? Our analysis of agency cost economics bears on several contemporary developments relating to these questions, and below we consider the implications of our findings for the direction restructuring may follow.

Significantly, the dominant strategies favored by major agencies a decade ago are now being abandoned or drastically revised. In the $1980^{\prime} \mathrm{s}$, a decline occured in the share of marketing budgets allocated to traditional mass media advertising by many large firms. At the same time, spending for consumer and trade promotions rose and the utilization of other modes of marketing communications such as direct response grew with the diffusion and application of information technology (Business Week [1991]; Jones [1993]). In response, numerous agencles expanded the range of services they offered, often through mergers and acquisitions, increasing both the scale and the scope of their operations (Millman [1988]; Winski [1991]).

However, beginning in the late 1980's and continuing to the present, aggregate spending on media advertising declined in real terms, driven in part by the prolonged recession in the U.S. economy (Jones (1993]). Faced with a mixture of adverse cyclical and secular conditions, the agency business has now entered into a period of experimentation. A variety of alternative strategies and structures have been proposed and introduced. These involve basic shifts in agency scale and scope, and represent a reversal of developments in the prior decade.

First, there is a resurgence of interest in "small" agencies (Sloan [1992]). In the past few years, a substantial number of cases have been reported wherein major advertisers have switched from very large to small or medium sized independent agencies - a noticeable departure from the traditional pattern of large clients preferring to work with large agencies (Goldman [1991]; Sloan [1992]). Furthermore, some of the largest conglomerate agencies have 
ADVERTISING AGENCIES AS MULTIPRODUCT FIRMS

themselves established small "spinoff" or satellite agencies, intended to match the service offered by small independents where clients perceive they can obtain superior creative work and more attention from senior agency personnel (Landler [1993]; Wells and Sloan [1993b].

our findings provide underpinnings to help understand these developments. We find that both the scale and scope economies available in producing various categories of media-related services can be largely realized at modest levels of agency size as measured by gross income. In particular, our results provide a basis for answering the question of how small can an agency be without suffering a serious loss in efficiency?

In our earlier work (Si1k and Berndt. [1993]), we found that to operate at minimum efficient size required gross income of $\$ 3-4$ million (1987 $\$$ ). 15 The results reported here indicate that the loss of efficiency incurred through operating at half that scale is minor - - less than 5\%. Furthermore, relatively small-sized agencies are able to exploit available scope economies as evidenced by our estimates that, depending on the media category, as few as $50 \%$ and as many as $85 \%$ of agencles in our sample were able to realize a cost advantage through the joint production of the $\mathrm{mlx}$ of media-related services they supplied.

Data reported in the 1987 Census of Services show that there were 493 agencies with gross incomes of $\$ 2.5 \mathrm{mflll}$ on or more operating in that year, and 1,512 agencies with gross incomes of $\$ 1$ million or more. Thus, it appears that agencies of widely varying sizes are economically viable.

The second area of policy undergoing change is the traditional concept of a "full service" agency where there is a movement toward the abandonment of "one-stop shopping" and the "unbundling" of services (Wells 11993]). The abandonment of "one stop shopplng" reflects a failure of agencies to realize the scope economies which earlier were expected to accompany diversification into such areas as direct marketing, sales promotion, and publication (Sellers 
[1993]; Wells [1993]). This diversification apparently occurred without effective integration of the various specialized groups. Efforts to cross-sell a broad range of services were resisted by clients who questioned the uniformity of the quality of diversified services avallable from a single agency and who doubted that one-stop shopping would produce significant savings in transactions costs.

Agencies that once aspired to be suppliers of a broad range of marketing communications services are now willing to offer clients creative and/or media services separately (Mandes [1994a]). Another related development is that some agencies have adopted a "general contractor" model whereby they offer a broad range of services but outsource certain of them to specialized suppliers (Mandese [1994b]; Wells and sloan [1993a]). Interestingly, this unbundling and the attention to small "boutique" agencies emphasizing creative services are consistent with policies advocated two decades ago by Gross [1972] as a means for developing more effective advertising.

Interpreted in light of our finding that substantial numbers of large agencies were operating with diseconomies of scope, this downsizing may reflect actions taken to correct excessive prior diversification. Bundling and conflict policy make for a "lumpy" product line adjustment process. Given that demand for agencies' services is cyclical and client turnover commonplace, product line shifts are frequent occurrences, but the task of maintaining efficiency in agency operations and avoiding diseconomies of scope is made difficult by the complexities which bunding and conflict policy impose.

The third area of agency policy undergoing change is compensation. Studies of compensation levels and methods indicate that over time, agencies' control over the pricing of their services has deteriorated as clients have become increasingly cost-conscious (Achenbaum [1990]; Lauterborn [1992]; Weilbacher [1990]). The evidence reported here indicating the presence of size- 
related economies is consistent with the trend away from the longstanding reliance on fixed commission rates, and the increased utilization of sliding scales of commissions and fees based on labor costs (Association of National Advertisers [1992]).

\section{SUMMARY AND CONCLUSIONS}

Th1s paper began by arguing that the basic structure of demand and costs in the advertising agency industry closely resembles those conditions which MacDonald and Slivinsk1 [1987] showed were essentlal for an industry to sustain a competitive equilibrtum consisting of diversified firms. Building on the evidence that the agency business is characterlzed by low fixed costs and minimal entry barriers, we hypothesized that both media-specific scale and scope economies could be exploited by relatively small-sized agencies. Our cross. sectional study produced support for both these hypotheses.

Two additional features of this industry were identified as exerting an important influence on market structure: (i)) client use of a mix of advertising media and the concomitant practice of agencies bundling their services; and (i1) the prohtbltion against an agency serving competing accounts which operates as a mobllity barrier. We hypothesized that the combined presence of these two phenomena could lead to excessive diversification, which would manifest itself In large agencies experlencing diseconomies of scope. Our empirical results also confirmed this relationship.

The results reported here serve to demonstrate the value of viewing advertising agencies as multiproduct firms, and offer a foundation for understanding the highly competitive and fragmented structure that has historlcally characterized the advertising industry. Further changes in agency scale and scope can be expected as agencies seek to position themselves for a wave of major innovations in communications technology and the possibilities of 
ADVERTISING AGENCIES AS MULTIPRODUCT FIRMS

a new era of interactive marketing (Blattberg and Deighton (1991)); Schrage

[1994]). The treatment of suppliers of communications services as multiproduct

firms should prove useful as a theoretical framework for analyzing the future evolution of the organization of this industry. 


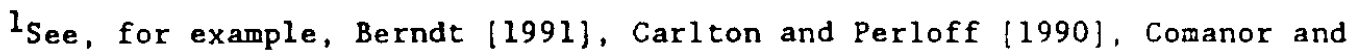
Wilson [1979], Hanssens, Parsons and Schultz [1990], Scherer and Ross [1990] and Schmalensee [1989].

2 The shares reported here were calculated by dividing the U.S. gross incomes for the largest 25, 100 and 500 agencies reported in Advertising Age $[1986,1988]$ by the total gross income (receipts) reported in the U.S. Census of Services for 1977 and 1987.

${ }^{3}$ Calculated from expenditures and price indices for national advertising in eight major media compiled by Robert Coen, Senior Vice President and Director of Forecasting, McCann-Erickson Worldwide, New York.

${ }^{4}$ Conflict policy is a neglected area of study within the advertising field, with two exceptions. Siman [1989] examined a large number of cases where conflicts arose as a result of agency or client mergers in the mid.1980's. Villas-Boas [1991] analyzed the conditions under which conflict policy may be justified in the case where competing advertisers are oligopolistic rivals.

${ }^{5}$ There is also evidence that the durability of agency-client relationships varies systematically across product categories (Buchanan and Michel [1987]). Hence, conflict policy not only affects the composition of an agency's service/media market, but it also affects the riskiness of its client/account portfollo and therefore its expected profitability.

${ }^{6}$ We contemplated using "flexible" functional forms such as the well-known translog function (see Berndt [1991]. Chapter 9), but found them to be impractical since in our sample, for many agencies a number of outputs take on zero values. With zero values, one cannot employ logarithmic forms such as the translog, and use of other polynomial transformations is also problematical.

7 parameter estimates and other econometric details relating to the estimation of this model are shown in Appendix B, Table Bl. Further discussion is given in Silk and Berndt [1993].

${ }^{8} \mathrm{~A}$ useful discussion of global scope economies and references to literature is given in Bailey and Friedlaender [1982].

${ }^{9}$ For a discussion of the nature of market equilibrium when economies of scope are present, see Eaton and Lemche [1991].

${ }^{10}$ This provides an interesting illustration of the point emphasized by Teece [1982], namely, that economies of scope by themselves are not sufficient to explain the existence and boundaries of multiproduct firms in a competitive industry, for transactions costs are necessary.

11 Table B2 in Appendix B presents sample summary statistics for the agency output variables discussed later in Section $V$.

${ }^{12}$ A discussion of some indirect evidence is provided in Silk and Berndt 11992, Appendix Al.

${ }^{13}$ See Table $B 1$ in Appendix B for details 
${ }^{14}$ The variability across the media reflects of course the underlying differences in the $\alpha_{j}$ parameter estimates described above.

${ }^{15}$ Those calculations employed Eq. (2) of this paper and therefore were based on the assumption that the firm was producing but one output. Thus those calculations ignored the multiproduct nature of firms in this industry, and the associated scope economies. Accordingly, our results here demonstrate that size-related cost penalties incurred by small agencies are very modest. due to available economies of scope. 


\section{REFERENCES}

Achenbaum, Alvin A. [1990], "Compensation Philosophy: The Client's View," in Negotiating Agency Compensation, New York: American Association of Advertising Agencies, 25-36.

Advertising Age [1988], "U.S. Advertising Agency Profiles," 59 (March 30), 4-26.

Advertising Age [1986], "Ten Year Gross Income Review of Top 25/200/500 Agencies," 57 (March 27), 92.

American Association of Advertising Agencies [1987], "Advertising Agencies: What They Are, What They Do, and How They Do It," New York City, NY.

American Association of Advertising Agencies [1985], "Longevity of Accounts in the Advertising Agency Business," New York Clty, NY.

American Association of Advertising Agencies [1979). "A Practical Solution to Client-Agency Account Conflicts," July, New York City, NY.

Association of National Advertisers [1992]. Trends in Agency Compensation, 1992, New York City, NY.

Association of National Advertisers [1986], Current Advertiser Practices in Compensating Their Advertising Agencles, New York City, NY.

Balley, Elizabeth E. and Ann F. Friedlaender [1982], "Market Structure and Multiproduct Industries," Journal of Economic Literature, 20 (September), $1024-1048$.

Beniger, James R. [1936], The Control Revolution, Cambridge: Harvard University Press.

Berndt, Ernst R. [1991], The Practice of Econometrics; Classic and Contemporary, Reading, MA: Addison-Wesley.

Blattberg, Robert C. and John Deighton [1991], "Interactive Marketing: Exploiting the Age of Addressability," Sloan Management Review, 33 (Fal1), $5 \cdot 14$.

Buchan, Bruce and Paul C. Michel1 [1991], "Using Structural Factors to Assess the Risk of Fallure in Agency-Client Relations, "Journal of Advertising Research, 31 (August-September), 68-75.

Business Week [1991], "What Happened to Advertising?", No. 3232 (September 23), $66-72$.

Carlton, Dennis W. and Jeffrey M. Perloff [1990], Modern Industrial Organization, Glenview, IL: Scott, Foresman.

Caves, Richard E. [1986], "Information Structures of Product Markets," Economic Inquiry, 24 (Apri1), 195-212.

Caves, Richard E. and Michael E. Porter [1977], "From Entry Barriers to Mobility Barriers: Conjectural Decisions and Contrived Deterrence to New Competition," Quarterly Journal of Economics. 91 (May), 241-261 
Coen, Robert J. (1988), "Ad Spending Rises 7.4\%," Advertising Age, 59 (June 13), 64.

Comanor, William S., Arthur J. Kover and Robert H. Smiley [1981], "Advertising and Its Consequences," in Paul C. Nystrom and William H. Starbuck, eds., Handbook of Organlzatlonal Design, Vol. 2, New York: Oxford University Press, 429-439.

Comanor, William S. and Thomas A. Wilson [1979], "The Effect of Advertising on Competition," Journal of Economic Literature, 17 (June), 453-476.

Eaton, B. Curt1s and Soren Q. Lemche [1991], "The Geometry of Supply, Demand, and Competitive Market Structure with Economies of Scope," American Economic Review, 91 (September), $901-911$.

Ezeklel, Mordecai and Karl A. Fox [1959], Methods of Correlation and Regression Analysis, 3rd Edition, New York: Wiley.

Gardner, Herbert S., Jr. [1976], The Advertising Agency Business, Chicago: Crain Books.

Goldman, Debra [1991], "Small Shops Take On a New Shine," ADWEEK, 32 (January 1, 1991), 1 and 7 .

Goldman, Debra [1992], "Mayhem on Madison: Agency Rivalries in the 1990's," ADWEEK, 33 (June 22), 17-20.

Gollop, Frank M. and James L. Monahan [1991), "A Generalized Index of Diversification Trends in U.S. Manufacturing," Review of Economics and Stat1stics, 73 (May), 318-330.

Gross, Irwin [1972], "The Creative Aspects of Advertising Strategy," Sloan Management Review, 14 (Fal1), 83-108.

Hanssens, Dominlque M., Leonard J. Parsons and Randall L. Schultz [1990], Market Response Models: Econometrfc and Time Series Analysis, Boston: Kluwer Academic Publishers.

Jaffe, Andrew [1994], "CKS Partners Issues Its Wakeup Call to Big Agencies," ADWEEK, 35 (April 4), 46.

Johnston, J. [1960], Statistical Cost Analysis, New York: McGraw-Hill.

Jones, John Phllip [1993], "Advertising's Crlsis of Confidence, " Marketing Management, 2, 15-24.

Landler, Mark [1993], "Mad Avenue Is Becoming Boutique Boulevard," Business Week, No. 3337 (September 20), 102-103.

Lauterborn, Robert F. (1992), "Accountability, Budgets, and Compensation Systems," The Advertiser, No. 4 (Fall), 66-69.

MacDonald, G. M. and A. Slivinski [1987], "The Simple Analytics of Competitive Equilibrium with Multiproduct Firms," American Economic Review, 77 (December), 941.953. 
Mandese, Joe [1994a], "Full Service Shops Lured to Media-Only Accounts," Advertising Age, 65 (January 31), 8.

Mandese, Joe [1994b], "Agencles Find Media Clout In Outside Services," Advertising Age, 65 (March 14), 3 and 44 .

Marshall, Christy [1988], "A Wave of Startups on Madison Avenue, " New York IImes, June 5, F13.

Mayer, Martin [1991], Whatever Happened To Madison Avenue?, Boston: Little, Brown.

Mayer, Martin [1959], Madison Avenue, U,S,A., New York: Pocket Books .

McDonald, H. E. [1989], "The Great Uneven Agency Playing Field: Some Perspectives On Agency Compensation and Profits, "New York: American Association of Advertising Agencies.

McNamara, Jay [1990], Advert1s Ing Agency Management, Homewood, IL: Irwin.

Mickelthwait, John [1990], "The Advertising Industry," Economist, 11 (June 9), $3 \cdot 18$.

Millman, Nancy. (1988), Emperors of Adland, Chicago: Warner Books.

Owen, Bruce M. and Steven S. Weldman [1992], V1deo Economics, Cambridge, MA: Harvard University Press.

Paster, Harry [1981]. "Measuring the Size of an Advertising Agency," American Assoclation of Advertising Agencles Newsletter, September, p. 2 .

Poltrack, David [1983], Television Marketing, New York: McGraw-Hil].

Pope, Danlel [1983], The Maklng of Modern Advertising, New York: Basic Books.

Porter, Michael E. [1976], "Interbrand Choice, Media Mix and Market Performance," Amerlcan Economlc Review, 66:2 (May), 398-406.

Rothenberg, Randal1 [1991], "Advertising's Antlc Upstarts," New York Times, (March 31), Section 3, 1 and 3

Scherer, F. M. and David Ross [1990], Industrlal Market Structure and Market Performance, Third Edition, Boston: Houghton Mifflin.

Schmalensee, Richard L. [1989], "Inter-Industry Studies of Structure and Performance," Chapter 16 in Richard Schmalensee and Robert Willig, eds., Handbook of Industrlal Organization, Vol. 2, New York: North-Holland, 951 . 1009 .

Schmalensee, Richard L., Alvin J. Silk and Robert Bojanek [1983], "The Impact of Scale and Media Mix on Advertising Agency Costs," Journal of Business, 56 (October), 453-475.

Schrage, Michael, Don Peppers, Martha Rogers and Robert D. Shapiro [1994], "Is Advertising Finally Dead?", Wired, (February), $71-75$ and $124-126$ 
Sellers, Patricia [1993], "Do You Need Your Agency?", Fortune, 128 (November 15), 147-164.

Silk, Alvin J. and Ernst R. Berndt [1993], "Scale and Scope Effects on Advertising Agency Costs," Marketing Science, 12 (Winter), in press.

Silk, Alvin J. and Ernst R. Berndt [1992], "Scale and Scope Effects on Advertising Agency Costs," Boston, MA: Harvard Business School, Division of Research, Working Paper 91-105 (Revised 1/92).

Siman, Salvador J. [1989], "Agency-Client Relationships Before and After Mergers in the Advertising Industry," unpublished M.S. thesis, Massachusetts Institute of Technology, Sloan School of Management.

Sloan, Pat [1992], "Smaller is Beautiful in '90's Fight for Accounts," Advertising Age, 63 (April 6), 1 and 14 .

Teece, David J. [1982], "Toward an Economlc Theory of the Multiproduct Firm," Journal of Economic Behavior and Organization, 3 (March), 39.63.

United States Bureau of Census [1989], 1987 Census of Service Industries, Geographic Area Series SC87-A-52, Washington, DC: U.S. Government Printing office.

United States Bureau of Census [1981], 1977 Census of Service Industries, Vol. 1. Subject Statistics, Washington, DC: U.S. Government Printing office.

Villas-Boas, J. Miguel [1991], "Proprietary Information in Vertical Relationships: The Advertising Agency Case," unpublished paper, Haas School of Business, University of California - Berkeley, December.

Wang. Judy S. and Ann F. Friedlaender [1985], "Truck Technology and Efficient Market Structure," Review of Economics and Statistics, 67 (August), 250 258.

Weilbacher, William M. [1991], Choosing and Working With Your Advertising Agency, Chicago: NTC Business Books.

Weilbacher, Willtam M. [1990], "What's Happening In Advertising Agency Compensation," in Negotiating Agency Compensation, New York: American Association of Advertising Agencies, 7-14.

Weilbacher, William M. [1989], Current Advertiser Practices in Compensating Their Advert1sing Agencles: 1989, New York: Association of National Advertisers.

Wells, Melanie [1993], "One-Stop Shopping Slips Away," Advertising Age, 64 (January 25), 1 and 44.

Wells, Melanie and Pat Sloan [1993a], "Four A's Fires Warning Shot," Advertising Age, 64 (Apri1 26), 1 and 47.

Wells, Melanie and Pat Sloan [1993b], "After Fattening Up For A Decade, Agencies Opt for Svelter Look," Advertising Age, 64 (August 23), 4 and 28 
Winski, Joseph W. [1990], "The Decade of the Deal," Advertising Age, 61 (January 1) $3-4$. 
FIGURE 1

\section{AGENCY SERVICE MIX}

Media

\section{Functions}

Output

Strategy Creative Media Production Research Other

Magazines

Newspapers

Radio

Television

Display

Direct

Response

Promotion

Public

Relations

Other 
TABLE 1

SUMMARY STATISTICS FOR MEDIUM-SPECIFIC SCALE ECONOMY ESTIMATES (SCL, $)$ *

\begin{tabular}{|c|c|c|c|c|c|c|}
\hline \multirow{2}{*}{$\begin{array}{l}\text { output } \\
\text { Media } \\
\text { Category } \\
\text { (j) }\end{array}$} & \multirow{2}{*}{$\begin{array}{l}\text { No. } \\
\text { Agencies } \\
\text { Producing } \\
\text { Output } \\
(j)\end{array}$} & \multicolumn{5}{|c|}{ Mediun-Specific Scale Economies $\left(\mathrm{SCL}_{\mathrm{f}}\right)$} \\
\hline & & Median & Mean & $\begin{array}{l}\text { Std. } \\
\text { Dev. }\end{array}$ & Maximum & Minimun \\
\hline $\begin{array}{l}\text { Network } \\
\text { Television }\end{array}$ & 217 & 2.592 & 2.651 & 0.541 & 4.162 & 1.532 \\
\hline $\begin{array}{l}\text { Spot } \\
\text { Television }\end{array}$ & 309 & 2.764 & 2.805 & 0.599 & 4.228 & 1.290 \\
\hline $\begin{array}{l}\text { General } \\
\text { Magazines }\end{array}$ & 366 & 2.800 & 2.902 & 0.565 & 4.228 & 1.808 \\
\hline $\begin{array}{l}\text { Specialty } \\
\text { Print }\end{array}$ & 268 & 2.795 & 2.854 & 0.525 & 4.145 & 1.538 \\
\hline Newspapers & 382 & 1.958 & 1.958 & 0.240 & 2.483 & 1.073 \\
\hline $\begin{array}{l}\text { Direct } \\
\text { Response }\end{array}$ & 259 & 2.042 & 2.016 & 0.242 & 2.477 & 1.090 \\
\hline Radio & 355 & 1.549 & 1.553 & 0.121 & 1.824 & 1.309 \\
\hline Display & 321 & 1.602 & 1.597 & 0.110 & 1.810 & 1.354 \\
\hline $\begin{array}{l}\text { Non-Media } \\
\text { Services }\end{array}$ & 364 & 1.416 & 1.424 & 0.189 & 2.106 & 0.985 \\
\hline
\end{tabular}

* SCL $L_{j}=A I C_{j} / M C_{j}$

where:

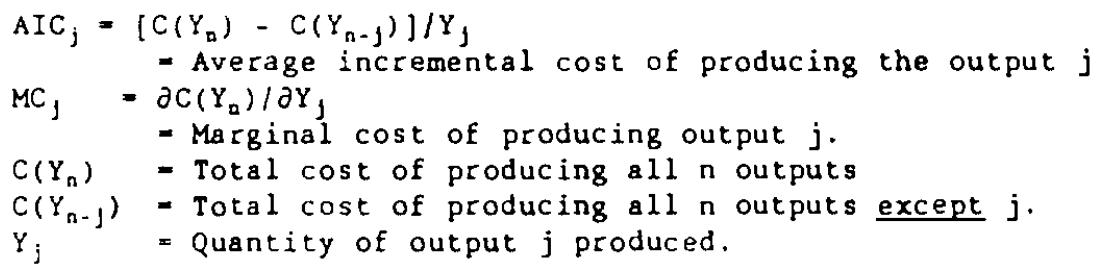


TABLE 2

SUMMARY STATISTICS FOR MEDIUM-SPECIFIC SCOPE ECONOMY ESTIMATES (SCP $)^{*}$

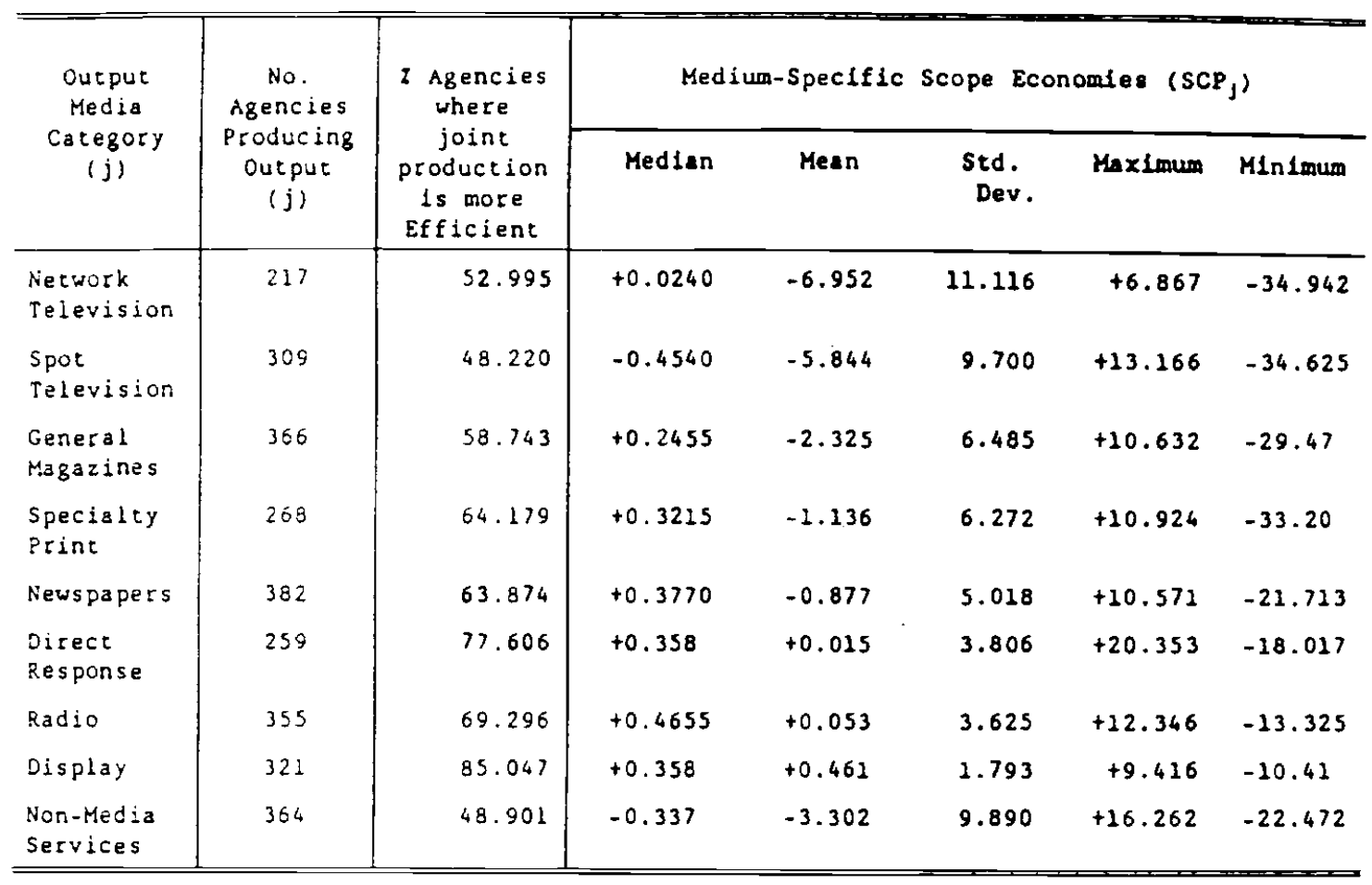

$$
\cdot S C P_{j}=\left\{\frac{C\left(\gamma_{\jmath}\right)+C\left(\gamma_{n-j}\right)-C\left(Y_{n}\right)}{C\left(Y_{0}\right)}\right\} \cdot 100
$$

where:

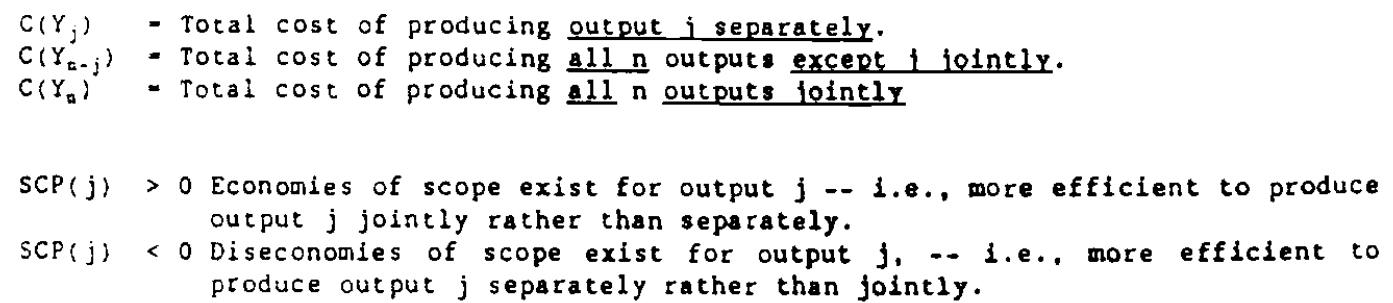




\section{ARPENDIX A}

DERIVATIONS OF INDICES FOR PRODUCT-SPECIFIC SCALE AND SCOPE ECONOMIES

Medium-Specific Scale Economies

Following Bailey and Friedlander (1982, p. 1030), we may define productspecific returns to scale for output $j$ :

$$
\begin{gathered}
\operatorname{SCL}_{j}=\frac{A I C_{j}}{M C_{j}} \\
A I C_{j}=\frac{\left[C\left(Y_{n}\right)-C\left(Y_{n-j}\right)\right]}{Y_{j}} \\
M C_{j}=\frac{\partial C\left(Y_{n}\right)}{\partial Y_{j}}
\end{gathered}
$$

where:

$$
\begin{aligned}
& \mathrm{AIC}_{j} \quad=\text { Average incremental cost of producing output } j, j=1 \text {, } \\
& \ldots . n \text {. } \\
& M C_{j} \quad=\text { Marginal cost of producing output } j . \\
& C\left(Y_{n}\right) \quad=\text { Total cost of producing all } n \text { outputs. } \\
& C\left(Y_{n}-j\right)=\text { Total cost of producing all } n \text { outputs except } j \text {. } \\
& Y_{j} \quad=\text { Quantity of output } j \text { produced, } \\
& Y_{n}=Y_{j}+Y_{n-j}=\sum_{j=1}^{n} Y_{j}
\end{aligned}
$$
i. throughout 
Now for our preferred "Scale Plus Scope" model the average cost is:

$$
U_{n}=\sum_{j=1}^{n} \alpha_{j} s_{j}+\beta \exp \left(\gamma_{n}\right)
$$

To get total cost, we multiply both sides of (4) by total output, $Y_{n}$. and obtain:

$$
C\left(Y_{n}\right)=Y_{n} \cdot U_{n}=Y_{n} \sum_{j=1}^{n} \alpha_{j} S_{j}+Y_{n} \beta \exp \left(\gamma_{n}\right)
$$

Noting that $Y_{j}=S_{j} Y_{n}$, where $S_{j}$ is share of total output represented by output $j$, we may re-write (5) as:

$$
C\left(Y_{n}\right)=\sum_{j=1}^{n} \alpha_{j} Y_{j}+Y_{n} \beta \exp \left(\gamma_{n}\right)
$$

An expression for the total cost of producing all $n$ outputs except $j$ may be obtained in a similar manner. Total output excluding $j$ is $Y_{n}-Y_{j}=Y_{n}(1-$ $\left.s_{j}\right)$ and thus from (4), unit cost becomes:

$$
U_{n-j}=\sum_{j=1}^{n-i} \alpha_{j} s_{j}+\beta \exp \left(\gamma\left(1-s_{j}\right) Y_{n}\right)
$$

To obtain total cost for total output excluding $j$, we multiply both sides of (7) by $Y_{n}\left(1-s_{j}\right)$ :

$$
\begin{aligned}
C\left(Y_{n-j}\right) & =\left(1-s_{j}\right) Y_{n}\left\{\sum_{k=1}^{n-1} \alpha_{k} s_{k}+\beta \exp \left(\gamma\left(1-s_{j}\right) Y_{n}\right)\right\} \\
& =\left\{\left(1-S_{j}\right) Y_{n} \sum_{k=1}^{n-1} \alpha_{k} s_{k}\right\}+\left(1-s_{j}\right) Y_{n} \beta \exp \left(\gamma_{n}\right) \exp \left(-\gamma S_{j} Y_{n}\right) .
\end{aligned}
$$


Substituting (6) and (8) for $C\left(Y_{n}\right)$ and $C\left(Y_{n}-j\right)$, respectively, in (2) and simplifying, we obtain:

$$
\left.A I C_{j}=\alpha_{j}-\sum_{k=1}^{n-1} \alpha_{k} s_{k}+\frac{\beta}{s_{j}} \exp \left(\gamma_{n}\right) \mid 1-\left(1-s_{j}\right) \exp \left(-\gamma s_{j} Y_{n}\right)\right]
$$

To obtain an expression for the marginal cost of $j, \mathrm{MC}_{j}$, we differentiate (6) with respect to $Y_{j}$. To do so, it is convenient to substitute $Y_{n}=Y_{j}+Y_{n-j}$ in $(6)$ :

$$
\begin{aligned}
C\left(Y_{n}\right) & =\alpha_{j} Y_{j}+\sum_{k=1}^{n-1} \alpha_{k} Y_{k}+\left(Y_{j}+Y_{n-j}\right) \beta \exp \left(\gamma\left(Y_{j}+Y_{n-j}\right)\right) \\
& =\alpha_{j} Y_{j}+\sum_{k=1}^{n-1} \alpha_{k} Y_{k}+Y_{j} \beta \exp \left(\gamma_{j}\right) \exp \left(\gamma_{n-j}\right)+Y_{n-j} \beta \exp \left(\gamma_{j}\right) \exp \left(\gamma_{n-j}\right) .
\end{aligned}
$$

where $j \neq k$.

$\frac{\partial C\left(Y_{n}\right)}{\partial Y_{j}}=\alpha_{j}+\frac{\partial}{\partial Y_{j}}\left[Y_{j} \beta \exp \left(\gamma_{j}\right) \exp \left(\gamma_{n-j}\right)\right]+\frac{\partial}{\partial Y_{j}}\left[Y_{n-j} \beta \exp \left(\gamma_{j}\right) \exp \left(\gamma_{n-j}\right)\right]$

Let the second term in the above equations be:

$$
W=z V=\beta Y_{j} \exp \left(\gamma Y_{j}\right) \exp \left(\gamma Y_{n-1}\right)
$$

where:

$$
\begin{gathered}
Z=\beta Y_{j} \exp \left(\gamma_{n-j}\right) \\
v=\exp \left(\gamma_{j}\right)
\end{gathered}
$$

Differentiating (12), (13) and (14), 


$$
\begin{gathered}
\frac{d W}{d Y_{j}}=z \frac{d V}{d Y_{j}}+v \frac{d z}{d Y_{j}} \\
\frac{d V}{d Y_{j}}=\gamma \exp \left(\gamma_{j}\right) \\
\frac{d z}{d Y_{j}}=\beta \exp \left(\gamma_{n-j}\right)
\end{gathered}
$$

Substituting (13), (14), (16) and (17) in (15) and simplifying:

$$
\frac{d W}{d Y_{j}}=\left(\gamma_{j}+1\right) \beta \exp \left(\gamma_{n}\right)
$$

The third term on the right hand side of (11).

$$
\frac{\partial}{\partial Y_{j}}\left[Y_{n-j} \beta \exp \left(\gamma_{j}\right) \exp \left(\gamma_{n-j}\right)\right]=\gamma_{n-j} \beta \exp \left(\gamma_{n}\right)
$$

Substituting (18) and (19) in (11), we get:

$$
M C_{j}=\alpha_{j}+\left[\gamma_{n}+1\right] \beta \exp \left(\gamma_{n}\right)
$$

Substituting (9) and (20) for $A I C_{j}$ and $M C_{j}$, respectively in (1), we obtain an expression for the index of product-specific scale economies in terms of the parameters of our preferred "Scale plus Scope" model (4) above: 


$$
\begin{aligned}
S C L_{j} & =\frac{A I C_{j}}{M C_{j}} \\
& =\frac{\alpha_{j}-\sum_{k=1}^{n-1} \alpha_{k} S_{k}+\frac{\beta}{S_{j}}\left[1-\left(1-S_{j}\right) \exp \left(-\gamma_{j} Y_{n}\right)\right] \exp \left(\gamma_{n}\right)}{\alpha_{j}+\left[1+\gamma_{n}\right] \beta \exp \left(\gamma_{n}\right)},
\end{aligned}
$$

where $j \neq k$.

Medium-Soecific Scope Economies

Product-specific scope economies are defined as (e.g., Wang and Friedlander, 1985, p. 253):

$$
S C P_{j}=\frac{C\left(Y_{j}\right)+C\left(Y_{n-j}\right)-C\left(Y_{n}\right)}{C\left(Y_{n}\right)}
$$

where:

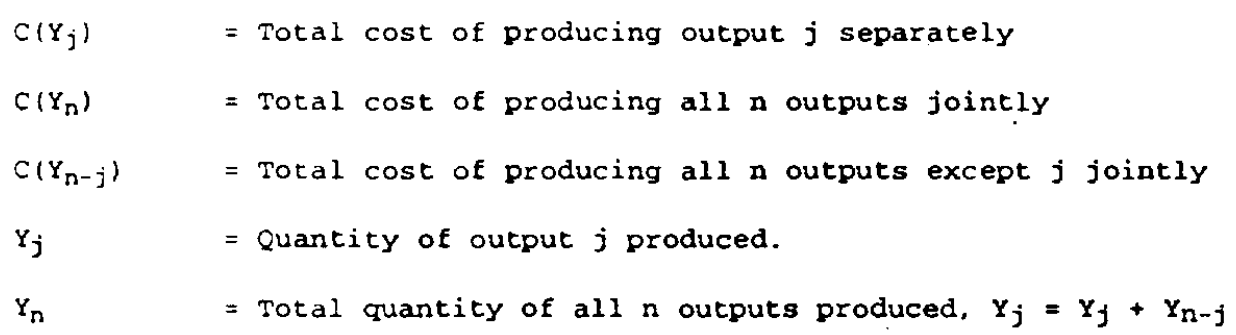

$$
u_{j}=\alpha_{j}+\beta \exp \left(\gamma_{j}\right)
$$


To obtain the total cost of producing $j$ separately, we multiply both sides of (23) by $Y_{j}$ :

$$
\begin{aligned}
C\left(Y_{j}\right) & =Y_{j} \cdot U_{j} \\
& =\alpha_{j} Y_{j}+Y_{j} \beta \exp \left(Y_{j}\right)
\end{aligned}
$$

Noting that $Y_{j}=S_{j} Y_{n},(24)$ may be re-written as:

$$
c\left(Y_{j}\right)=s_{j} Y_{n}\left[\alpha_{j}+\beta \exp \left(\gamma s_{j} Y_{n}\right)\right]
$$

Substituting (5), (8), and (25) in (22) for $C\left(Y_{n}\right), C\left(Y_{n-j}\right)$, and $C\left(Y_{j}\right)$, respectively, we obtain:

$S C P(i)=\frac{s_{j}\left[\alpha_{j}+\beta \cdot \exp \left(\gamma S_{j} Y_{n}\right)\right]+\left(1-s_{j}\left[\left[\sum_{k=1}^{n-1} \alpha_{k} s_{k}+\beta \cdot \exp \left(\gamma\left(1-s_{j}\right) Y_{n}\right)\right]\right.\right.}{\sum_{m=1}^{n} \alpha_{m} s_{n}+\beta \cdot \exp \left(\gamma_{n}\right)}-1$

where $j \neq k$ and $m$ denotes specific media output $m$. 
APPENDIX B

TABLE B1

SUMMARY STATISTICS FOR AGENCY OUTPUT VARIABLES

\begin{tabular}{|c|c|c|c|c|c|}
\hline Variable and Measure & Median & Mean & Std. Dev. & Maximum & MInimun \\
\hline \multicolumn{6}{|l|}{ Product Line Breadth } \\
\hline $\begin{array}{l}\text { Number of Different } \\
\text { Media Outputs Produced }\end{array}$ & 7 & 7.085 & 1.467 & 9 & 2 \\
\hline \multicolumn{6}{|l|}{ Product Line Consolidation } \\
\hline $\begin{array}{l}\text { Herfindahl Index of } \\
\text { output Concentration }\end{array}$ & 0.225 & 0.307 & 0.226 & 0.931 & 0.022 \\
\hline \multicolumn{6}{|l|}{ Agency Size } \\
\hline $\begin{array}{l}\text { Natural log of Agency } \\
\text { Gross Income ( } \$ 10 \text { mill.) }\end{array}$ & -1.129 & -0.907 & 1.309 & 3.349 & -3.275 \\
\hline \multirow{2}{*}{\multicolumn{6}{|c|}{$\begin{array}{l}\text { Media Shares of Total } \\
\text { Agency Billings }(x)\end{array}$}} \\
\hline & & & & & \\
\hline Network Television & 5.556 & 13.791 & 16.625 & 64.941 & 0.105 \\
\hline Spot Television & 12.195 & 16.138 & 15.183 & 79.962 & 0.031 \\
\hline General Magazines & 7.588 & 10.295 & 9.524 & 63.636 & 0.017 \\
\hline Specialty Print & 4.677 & 8.689 & 11.273 & 65.000 & 0.063 \\
\hline Newspapers & 6.252 & 9.390 & 11.074 & 80.643 & 0.080 \\
\hline Direct Response & 2.975 & 7.182 & 12.974 & 91.614 & 0.034 \\
\hline Radio & 5.517 & 6.768 & 5.830 & 30.238 & 0.050 \\
\hline Display & 1.505 & 2.971 & 4.210 & 31.765 & 0.001 \\
\hline Non-Media Services & 45.165 & 47.309 & 27.312 & 97.366 & 0.002 \\
\hline
\end{tabular}


APPENDIX B

Table B2

Maximum Likel thood Estimates of Parameters for Preferred S\&S Model (Ratio of Parameter Estimate to Robust Standard Error in Parentheses)

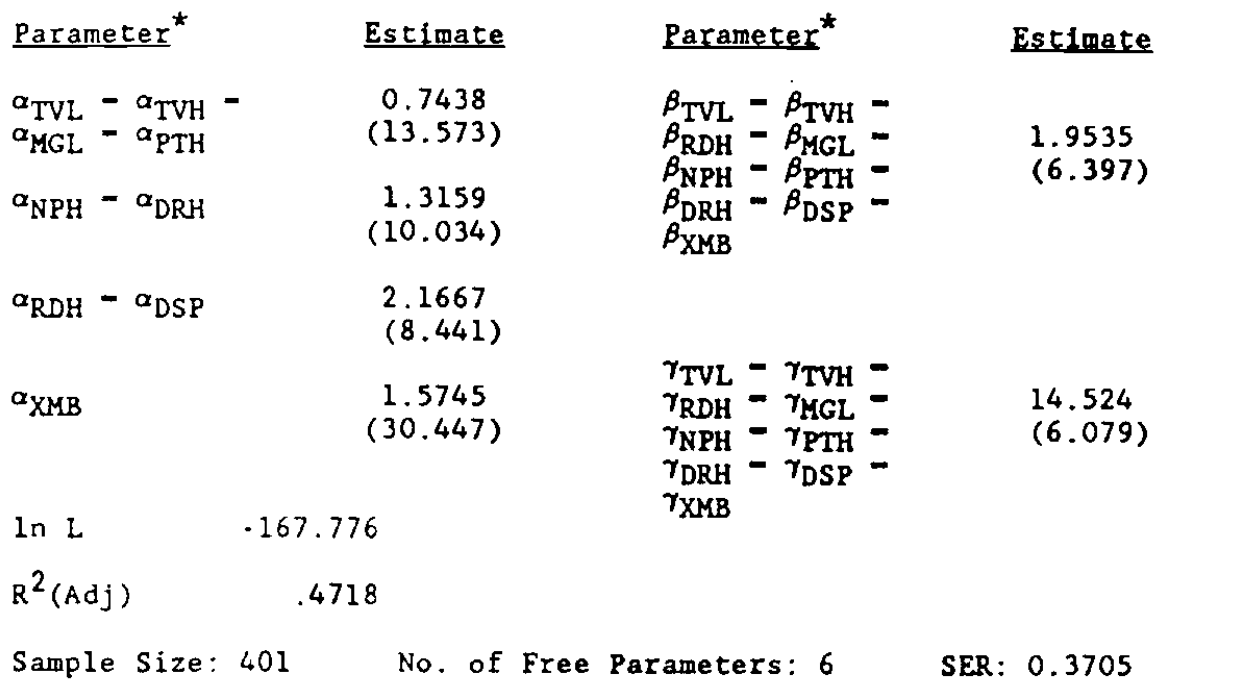


APPENDIX C

CROSS-SECTIONAL PRODUCT-SPECIFIC SCALE AND SCOPE REGRESSIONS

\section{Product-Specific Scale Results}

Recall from Eq. (14) in the text that our measure of product-speciflc scale economies, $S C L_{i k}$, Indicates the extent to which an agency 1 exploits the potential scale economies avallable as $1 t$ adds a medium $k$ to 1 ts product line and thereby increases the volume of output it produces in that category from zero to some particular level, $Y_{i k}$. Consistent with this definition, it is of Interest to examine how an agency's reallzation of the avallable scale economles for that media category $k$ varies with the scale and composition of its output excluding that category $k$ - the particular medium or product under consideration. Accordingly, we employ the following set of agency descriptor variables:

Single Product

Concentration $\left(S_{i k}\right)$

Agency Size ( $\left.\ln Y_{i}^{\prime}\right)$

Product Line Breadth ( $n_{i}^{\prime}$;

Product Line Specialization $\left(D_{j}\right)$
Medla category $k$ 's share of an agency l's total output (gross Income, $Y_{1}$ )

Natural log of agency l's gross Income, excluding income from medlum $k$ : $Y_{1}$ $\left(1-s_{i k}\right) \cdot Y_{i}$

Number of different media categorles for which $Y_{1 j}>0$, called $n_{1}$, where $j-1, \ldots, k, \ldots, n_{1} \ldots, N$, and then excluding one output $k$ : $n_{1}-n_{1}-1$

Index of product line speclalization for agency $1, D_{1}$, whose value may range from zero (when output is perfectly diversifled or equally distributed across all $n_{1}$ categorles, 1.e., $s_{1 j}-1 / n_{1}$, for all j) to unity (when $S_{1 f}=1$ for some particular medium $j$ ). More speciflcally, for agency 1 excluding output $k, D_{1}$ is defined as: ${ }^{1}$

$$
\begin{gathered}
D_{1}-\left[H\left(n_{1}^{\prime}\right)-H(m \mid n)\right] /[1-H(m 1 n)] \\
\text { where } H\left(n_{1}^{\prime}\right)-\sum_{j=1}^{n_{1}^{1}}\left(s_{1 j}^{\prime}\right)^{2}, j+k, \\
s_{1 j}^{\prime}=s_{1 j} /\left(1-s_{1 k}\right) \text {, and } \\
H(m 1 n)=\sum_{j=1}^{n_{1 j}}\left(\frac{1}{n_{i}}\right)^{2}-\frac{1}{n_{i}} .
\end{gathered}
$$


To facilitate comparisons of regression results across media categories, we computed standardized regression coefficients that are similar to conventional partial regression coefficients except that each variable is scaled in units of the sample value of its standard deviation (Ezekiel and Fox [1959]). ${ }^{2}$ To illustrate, in this application a standardized regression coefficient measures the magnitude of change in a medium-specific scale economy index $\left(\operatorname{SCL}_{1}\right)$, expressed as a proportion of the sample value of its standard deviation associated with a change in one standard deviation in some explanatory variable.

In Table C-I we display the values of these standardized coefficients obtained by regressing each of the nine medium-specific scale economy indexes separately on the set of four agency output variables. These regressions are intended to serve only as a means of describing how scale economies covary with agency characteristics; it would, of course, be inapproprlate to draw any deep structural or statistical inferences from these results.

\section{INSERT TABLE C-1 HERE}

Examining Table C-I, we see that realization of scale economies is related to the size and composition of an agency's output in essentially the same systematic manner in each of the media categories--as Indicated by the consistency of the signs and relative magnitudes of the standardized regression coefficients for three of the four descriptor variables: category share of total output, $\log$ gross income, and the product line specialization index. No consistent pattern of effects emerged for the product line breadth measure (the number of different media categories encompassed by an agency's output), as evidenced by instability in the signs of the relevant standardized regression coefficients and generally small magnitudes relative to their standard errors. 
The adjusted $R^{2}$ statistics reveal that the set of four agency output variables account for half or more of the cross sectional variability in each of the medium-specific scale economy Indices, except for the specialty print category where the fit is somewhat lower $\left(R_{a d j}^{2}-0.453\right)$.

These results imply that when an agency expands Its output by adding a category to its media mix, the greater Its prior size and the more diversifled its existing media mix, the greater will be the extent to which 1 captures the available scale economies. ${ }^{3}$ Product-Specific Scope Results

In Table $C-2$ we present the results obtained when each mediun-specific scope economy index was regressed on a set of four agency output descriptor variables similar to those investigated in the preceding analysis of scale economies. By definition, product-specific scope economies are zero when a INSERT TABLE C-2 HERE

product's share of total output is either zero or unfty (see Eqs. (15) and (16)) and hence, the relationship between scope economy and output share is nonmonotonic. Accordingly, we employed a quadratic specification for the cateogry share variable. In Table C-2 standardized regression coefficients are given for the linear and squared share terms. As in the analysis of scale economies, measures of agency size and product line speclalfzation and breadth were also included in the regression. The values of the measures of these varlables used in the medium-speccific scope regressions reported in Table C-2 reflect each agency's entire product line. ${ }^{4}$

Inspecting Table $C-2$, we find that the signs of the standardized regression coefficients for each of the explanatory variables are almost perfectly consistent across the entire set of nine media-related output categorles. As 
indicated by the values of the adjusted $R^{2}$, together the four varlables accounted for roughly $50-80 z$ of the variance in seven of the nine scope economy indices. The exceptions are the direct response and display categorles where the crosssectional variation is comparatively limited, as may be seen from Table 2 in the text which indicates that 78 and $85 \%$ of the agencles operating in these respective categories realize a cost advantage through jolnt production.

The signs and magnitudes of the estimated coefficlents for the quadratic relation between scope economies and media share Indicate that throughout most of the relevant operating range, the relationship is a negative one. 5 That is to say, the cost advantage from joint production tends to decline as an agency's output becomes increasingly concentrated in any single media category. The exception is again the display category where the within-sample variabllity in scope economies is smallest and no systematic pattern of relationship between scope economies and share is discernible.

Turning to the results for the agency size and product line specialization relationship, we see from Table C-2 that, with a single exception, the standardized regression coefficlents all have negative signs and appear otherwlse stable in the sense that the magnitudes of the coefficlents are at least twice (and most of ten more than three times) the size of their standard errors. The discrepant case is non-media services where the sign of the standardized regression coefficient for the product line specialization Index is reversed (positive), but the size of the coefficient is less than twice its estimated standard error.

An examination of the results for product line breadth, measured by the number of different media output produced, Indicates that the sign of the standardized regression coefficient is negative for eight of the nine media categories. However, the effect appears small and/or Imprecisely estimated, as 
indicated by the fact that in only two cases (general magazines and specialty print) is the size of the coefficlent more than twlce lts standard orror.

Overall then, our results indicate that the cost advantage assoclated with the joint as opposed to the separate production of a particular category of media advertising tends to decline with increases in: (1) the share of total agency output concentrated in that media category; (11) agency size; and (111) specialization of the agency's media $\mathrm{mlx}$. While most agencles produce service mixes that enable them to realize the benefits of jolnt production, we also find Instances where agencles appear to have become too large and/or overly speclalized in the sense that their operations are characterized by diseconomies of scope, and cost savings could be realized by realigning their media mixes and/or separating operations.

Noce that media-specific scale and scope economes are related to agency size and media share in the same manner: the greater the share a particular category of media advertising represents in the agencoy's total output and the larger the agency, the more likely it is that an agency will have exhausted both the scale and scope economies avallable for any of the categorles of medis advertising that it produces. However product line diversiflcation (or specialization) is related to scale and scope economies in epposite ways. Whereas it is the agencies with more diversified (less speclalized) media mixes that are more likely to have explofted scale economies, it is the more speciallzed (less diversifled) agencles who operate with the smallest scope economies or perhaps who may even experlence diseconomles of scope. 
This index of output specialization is a normalized version of the famflar Herfindahl Index (H) often used as a measure of output concentration across firms within an industry. Here we apply tt to measure concentration of a single firm's output across its product line. Since the lower bound of $H$ varies with $n$, it is not well suited for use in cross sectional comparisons like the present situation where the agencies differ in the number of media categories $(n)$ in which they produce output. To circument this problem, we adopted the normalization shown below which rescales $H$ for any particular $n$ relative to its lower bound, thereby yielding a diversification measure whose range is independent of $n$.

In Appendix B, Table Bl, we present summary sample statistics for the set of four variables employed here to characterize the size and composition of an agency's output.

${ }^{3}$ There is one exception to this pattern and that occurs for the non-media services category where the sign of the standardized regression coefficient reported in Table 2 indicates that the capturing scale economies increases with greater specialization of an agency's media mix. This is the reverse of the relationship found for the other eight categories, where the less specialized (or the more diversified) an agency's existing media mix, the more of the available scale economies it captures when expanding its media offerings. We suspect that this apparent anomoly may be attributable to the heterogeneous nature of this composite output category which includes a broad array of services. Our suspicion of aggregation issues here is reenforced by the fact that the mean and variance of this category's share of agency's output is larger than those of any of the other eight categorfes.

${ }^{4}$ Recall that for the product-specific scale economy regressions, the size, product line specialization and breadth varlables were defined so as to exclude the particular product (medium) under consideration. This modification in the definitions of these three variables when used as regressors in scope rather than scale regressions is necessary in order to be consistent with the nature of the cost comparisons underlying the concepts of product-specific scale and scope economies. Product-speciflc scale economles describe the behavior of costs when total output is increased by adding another product to the existing line. In contrast, product-specific scope economies reflect the comparative costs of producing the same product line and total output in two different ways.

${ }^{5}$ The proportion of agencies with media share which exceeded the values of the inflexion point implied by the estimated coefficients from the quadratic scope-share regressions varied from zero for network television to seven percent for radio and 30 percent for non-media services. 
REGRESSION RESULTS: MEDIUM-SPECIFIC SCALE ECONOMIES REGRESSED ON FOUR AGENCY OUTPUT VARIABLES

\begin{tabular}{|c|c|c|c|c|c|c|}
\hline \multirow[b]{2}{*}{$\begin{array}{c}\text { Output } \\
\text { Media } \\
\text { Category j }\end{array}$} & \multirow[b]{2}{*}{$\begin{array}{l}\text { No. of } \\
\text { Agencies } \\
\text { Producing } \\
\text { Output j }\end{array}$} & \multirow[b]{2}{*}{$R^{2}(\operatorname{Adj})}$. & \multicolumn{4}{|c|}{$\begin{array}{l}\text { Standardized Regression Coefficients } \\
\text { (Ratio of Coefficient to Standard Error) }\end{array}$} \\
\hline & & & $\begin{array}{c}\text { Category } \\
\text { j's } \\
\text { Share of } \\
\text { Agency } \\
\text { Total } \\
\text { Output }\end{array}$ & $\begin{array}{c}\text { Log } \\
\text { Agency } \\
\text { Gross } \\
\text { Income* }\end{array}$ & $\begin{array}{l}\text { Output } \\
\text { Speciali- } \\
\text { zation } \\
\text { Index* }\end{array}$ & $\begin{array}{l}\text { No. of } \\
\text { Medis } \\
\text { Outputs } \\
\text { Produced }\end{array}$ \\
\hline $\begin{array}{l}\text { Network } \\
\text { Television }\end{array}$ & 217 & .634 & $\begin{array}{l}-0.603 \\
(12.419)\end{array}$ & $\begin{array}{l}-0.275 \\
(6.267)\end{array}$ & $\begin{array}{l}+0.139 \\
(3.075)\end{array}$ & $\begin{array}{l}+0.027 \\
(0.608)\end{array}$ \\
\hline $\begin{array}{l}\text { Spot } \\
\text { Television }\end{array}$ & 309 & .626 & $\begin{array}{l}-0.547 \\
(13.913)\end{array}$ & $\begin{array}{l}-0.395 \\
(10.771)\end{array}$ & $\begin{array}{l}+0.162 \\
(3.976)\end{array}$ & $\begin{array}{l}-0.053 \\
(1.507)\end{array}$ \\
\hline $\begin{array}{l}\text { General } \\
\text { Magazines }\end{array}$ & 366 & .532 & $\begin{array}{l}-0.393 \\
(10.328)\end{array}$ & $\begin{array}{l}-0.467 \\
(12.249)\end{array}$ & $\begin{array}{l}+0.199 \\
(4.918)\end{array}$ & $\begin{array}{l}-0.029 \\
(0.777)\end{array}$ \\
\hline $\begin{array}{l}\text { Specialty } \\
\text { Print }\end{array}$ & 268 & .453 & $\begin{array}{l}-0.417 \\
(8.131)\end{array}$ & $\begin{array}{l}-0.429 \\
(8.523)\end{array}$ & $\begin{array}{l}+0.300 \\
(5.738)\end{array}$ & $\begin{array}{l}+0.087 \\
(1.589)\end{array}$ \\
\hline News papers & 382 & .606 & $\begin{array}{c}-0.463 \\
(13.205)\end{array}$ & $\begin{array}{c}-0.382 \\
(10.645)\end{array}$ & $\begin{array}{l}+0.330 \\
(8.700)\end{array}$ & $\begin{array}{l}+0.057 \\
(1.701)\end{array}$ \\
\hline $\begin{array}{l}\text { Direct } \\
\text { Response }\end{array}$ & 259 & .579 & $\begin{array}{c}-0.620 \\
(13.529)\end{array}$ & $\begin{array}{l}-0.377 \\
(8.422)\end{array}$ & $\begin{array}{l}+0.288 \\
(6.237)\end{array}$ & $\begin{array}{l}+0.099 \\
(2.017)\end{array}$ \\
\hline Radio & 355 & .662 & $\begin{array}{c}-0.391 \\
(11.219)\end{array}$ & $\begin{array}{c}-0.351 \\
(10.149)\end{array}$ & $\begin{array}{c}+0.418 \\
(11.240)\end{array}$ & $\begin{array}{l}+0.023 \\
(0.402)\end{array}$ \\
\hline Display & 321 & .563 & $\begin{array}{l}-0.305 \\
(7.839)\end{array}$ & $\begin{array}{l}-0.407 \\
(9.840)\end{array}$ & $\begin{array}{l}+0.426 \\
(10.087)\end{array}$ & $\begin{array}{l}+0.039 \\
(1.000)\end{array}$ \\
\hline $\begin{array}{l}\text { Non-Media } \\
\text { Services }\end{array}$ & 364 & .731 & $\begin{array}{c}-1.151 \\
(30.489)\end{array}$ & $\begin{array}{c}-0.620 \\
(16.008)\end{array}$ & $\begin{array}{l}-0.109 \\
(3.664)\end{array}$ & $\begin{array}{l}-0.008 \\
(0.265)\end{array}$ \\
\hline
\end{tabular}

*Excluding output $j$. 
TABLE C-2

REGRESSION RESULTS: MEDIUM-SPECIFIC SCOPE ECONOMIES

REGRESSED ON FOUR AGENCY OUTPUT VARIABLES

\begin{tabular}{|c|c|c|c|c|c|c|c|}
\hline \multirow[b]{2}{*}{$\begin{array}{l}\text { Output } \\
\text { Media } \\
\text { Category } \\
(j)\end{array}$} & \multirow[b]{2}{*}{$\begin{array}{l}\text { No. of } \\
\text { Agencies } \\
\text { Producing } \\
\text { Output }\end{array}$} & \multirow[b]{2}{*}{$(\Lambda d j)$} & \multicolumn{5}{|c|}{$\begin{array}{l}\text { Standardized Regression Coefficients } \\
\text { (Ratio of Coefficiont to Standard Error) }\end{array}$} \\
\hline & & & $\begin{array}{c}\text { Category } \\
\text { j Share } \\
\text { of } \\
\text { Agency } \\
\text { Total } \\
\text { Output } \\
\end{array}$ & $\begin{array}{c}\text { Square } \\
\text { of } \\
\text { Category } \\
\text { j Share } \\
\text { of } \\
\text { Agency } \\
\text { Total } \\
\text { Output }\end{array}$ & $\begin{array}{l}\text { Log } \\
\text { Agency } \\
\text { Gross } \\
\text { Income }\end{array}$ & $\begin{array}{l}\text { Output } \\
\text { Special1- } \\
\text { zation } \\
\text { Index }\end{array}$ & $\begin{array}{l}\text { No. of } \\
\text { Media } \\
\text { Outputs } \\
\text { Produced }\end{array}$ \\
\hline $\begin{array}{l}\text { Network } \\
\text { Television }\end{array}$ & 217 & .824 & $\begin{array}{l}-1.035 \\
(9.239)\end{array}$ & $\begin{array}{l}+0.296 \\
(2.843)\end{array}$ & $\begin{array}{l}-0.304 \\
(9.074)\end{array}$ & $\begin{array}{l}-0.068 \\
(1.994)\end{array}$ & $\begin{array}{l}-0.018 \\
(0.583)\end{array}$ \\
\hline $\begin{array}{l}\text { Spot } \\
\text { Television }\end{array}$ & 309 & .712 & $\begin{array}{l}-1.060 \\
(9.939)\end{array}$ & $\begin{array}{l}+0.542 \\
(5.373)\end{array}$ & $\begin{array}{c}-0.542 \\
(16.123)\end{array}$ & $\begin{array}{l}-0.176 \\
(4.222)\end{array}$ & $\begin{array}{l}-0.051 \\
(1.643)\end{array}$ \\
\hline $\begin{array}{l}\text { General } \\
\text { Magazines }\end{array}$ & 366 & .571 & $\begin{array}{l}-0.589 \\
(6.432)\end{array}$ & $\begin{array}{l}+0.176 \\
(2.045)\end{array}$ & $\begin{array}{l}-0.627 \\
(16.432)\end{array}$ & $\begin{array}{l}-0.157 \\
(3.658)\end{array}$ & $\begin{array}{l}-0.085 \\
(3.658)\end{array}$ \\
\hline $\begin{array}{l}\text { Specialty } \\
\text { Print }\end{array}$ & 268 & .469 & $\begin{array}{l}-0.661 \\
(5.183)\end{array}$ & $\begin{array}{l}-0.008 \\
(0.063)\end{array}$ & $\begin{array}{l}-0.439 \\
(8.799)\end{array}$ & $\begin{array}{l}-0.193 \\
(3.686)\end{array}$ & $\begin{array}{l}-0.115 \\
(2.150)\end{array}$ \\
\hline News papers & 382 & .522 & $\begin{array}{l}-0.757 \\
(7.341)\end{array}$ & $\begin{array}{l}+0.346 \\
(3.537)\end{array}$ & $\begin{array}{c}-0.686 \\
(17.258)\end{array}$ & $\begin{array}{l}-0.279 \\
(5.767)\end{array}$ & $\begin{array}{l}+0.004 \\
(0.105)\end{array}$ \\
\hline $\begin{array}{l}\text { Direct } \\
\text { Response }\end{array}$ & 259 & .235 & $\begin{array}{l}-0.667 \\
(4.236)\end{array}$ & $\begin{array}{l}+0.509 \\
(3.384)\end{array}$ & $\begin{array}{l}-0.487 \\
(8.201)\end{array}$ & $\begin{array}{l}-0.240 \\
(3.585)\end{array}$ & $\begin{array}{l}-0.117 \\
(1.800)\end{array}$ \\
\hline Radio & 355 & .472 & $\begin{array}{l}-0.478 \\
(3.854)\end{array}$ & $\begin{array}{l}+0.340 \\
(2.951)\end{array}$ & $\begin{array}{l}-0.749 \\
(17.300) .\end{array}$ & $\begin{array}{l}-0.338 \\
(6.435)\end{array}$ & $\begin{array}{l}-0.00001 \\
(0.0004)\end{array}$ \\
\hline Display & 321 & .317 & $\begin{array}{l}+0.029 \\
(0.253)\end{array}$ & $\begin{array}{l}+0.156 \\
(1.399)\end{array}$ & $\begin{array}{l}-0.539 \\
(10.404)\end{array}$ & $\begin{array}{l}-0.232 \\
(4.207)\end{array}$ & $\begin{array}{l}-0.003 \\
(0.064)\end{array}$ \\
\hline $\begin{array}{l}\text { fion-Media } \\
\text { Services }\end{array}$ & 364 & .623 & $\begin{array}{l}-0.848 \\
(4.965)\end{array}$ & $\begin{array}{l}+0.631 \\
(2.515)\end{array}$ & $\begin{array}{l}-0.738 \\
(2.555)\end{array}$ & $\begin{array}{l}+0.174 \\
(1.501)\end{array}$ & $\begin{array}{l}-0.047 \\
(1.373)\end{array}$ \\
\hline
\end{tabular}

